Portland State University

PDXScholar

1993

\title{
The Intellectual Grounding of the San Francisco Committee of Vigilance of 1851
}

Jon Jeffrey Walker

Portland State University

Follow this and additional works at: https://pdxscholar.library.pdx.edu/open_access_etds

Part of the United States History Commons

Let us know how access to this document benefits you.

Recommended Citation

Walker, Jon Jeffrey, "The Intellectual Grounding of the San Francisco Committee of Vigilance of 1851" (1993). Dissertations and Theses. Paper 1277.

https://doi.org/10.15760/etd.1276

This Thesis is brought to you for free and open access. It has been accepted for inclusion in Dissertations and Theses by an authorized administrator of PDXScholar. Please contact us if we can make this document more accessible: pdxscholar@pdx.edu. 
THE INTELLECTUAL GROUNDING OF THE SAN FRANCISCO

COMMITTEE OF VIGILANCE OF 1851

\author{
by \\ JON JEFFREY WALKER
}

A thesis submitted in partial fulfillment of the requirements for the degree of

MASTER OF ARTS

in

HISTORY

Portland State University

(c) 1993 
TO THE OFFICE OE' GRADUATE STUDIES:

The members of the Committee approve the thesis of Jon Jeffrey Walker presented July 1, 1993.

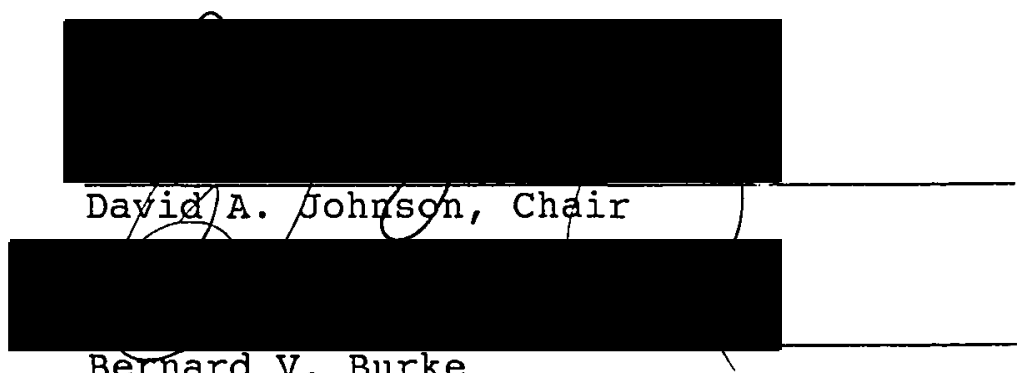

Bernard V. Burke

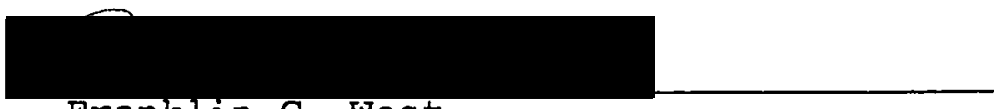

Franklin C. West
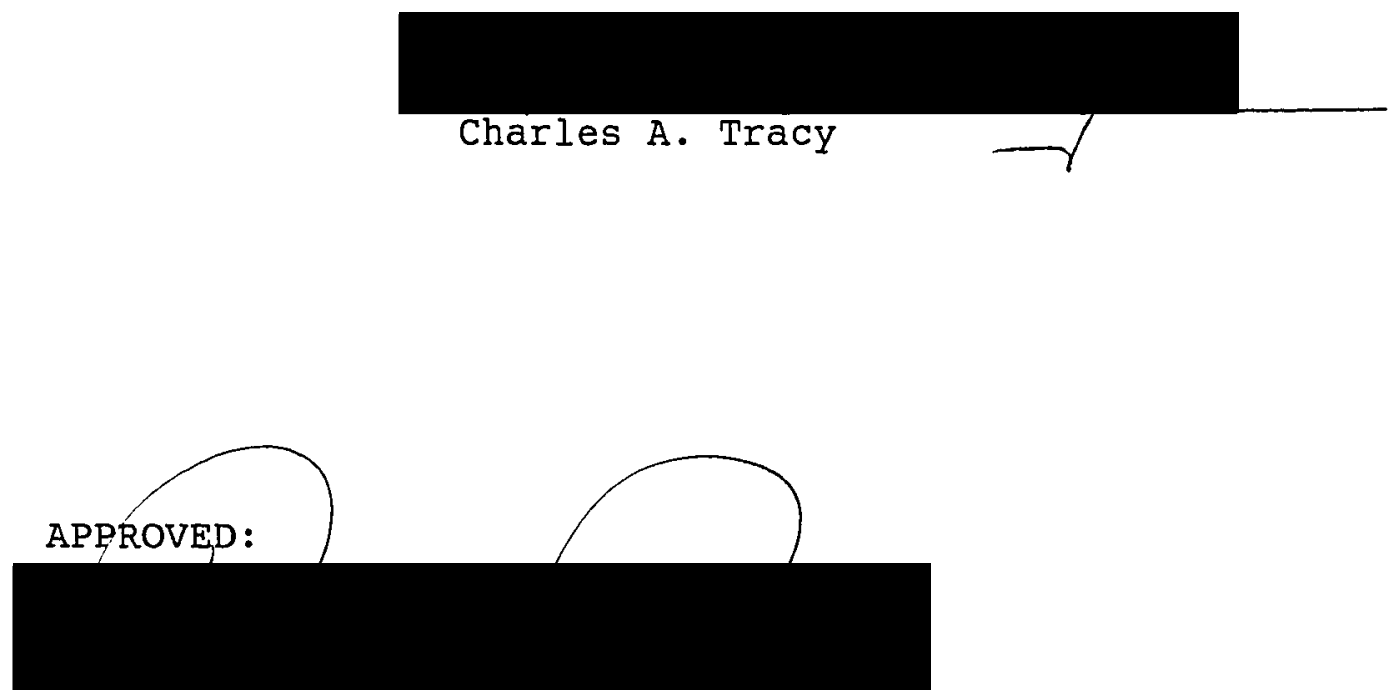

Bernard V. Burke, Chair, Department of History

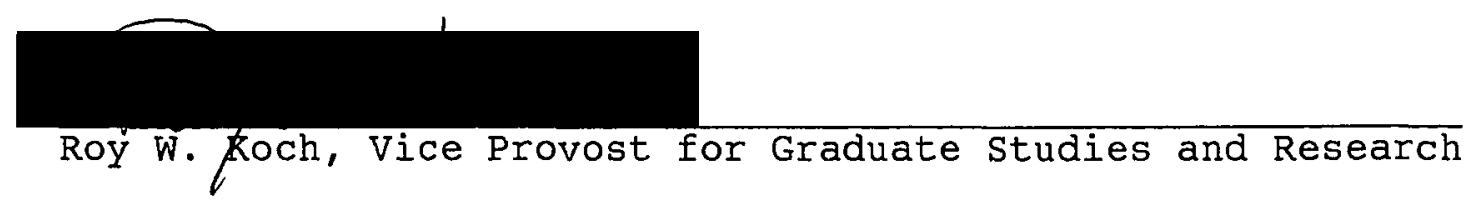


AN ABSTRACT OF THE THESIS OF Jon Jeffrey Walker for the Master of Arts in History presented July, 1, 1993.

Title: The Intellectual Grounding of the San Francisco Committee of Vigilance of 1851

APPROVED BY THE MEMBERS 9 F THE THESIS COMMITTEE:

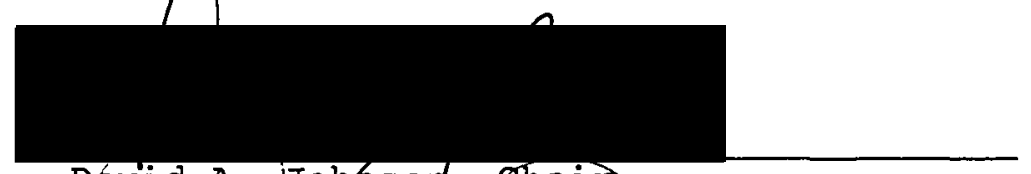
Dávid A. johnsoy, Chair

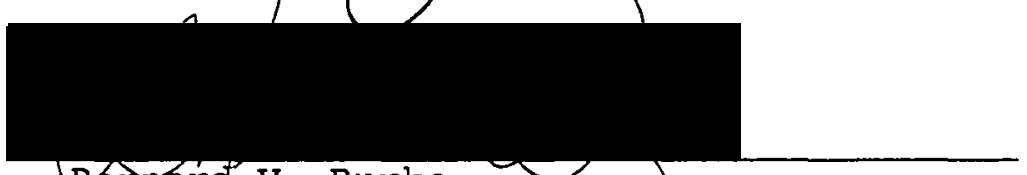

Bernard V. Burke

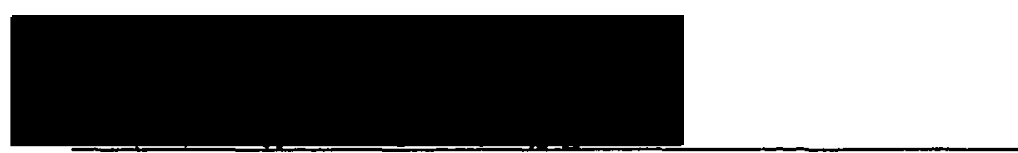

Franklin C. West

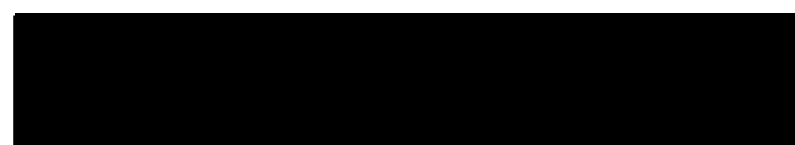

Charles A. Tracy

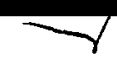

Vigilantism has a long history in the United States stretching back to the Regulator movement in South Carolina in 1767. These extralegal movements are distinguished from spontaneous and ephemeral mob activity by their regular organization and limited life-span. The San Francisco Committee of Vigilance of 1856 was the largest vigilante movement in American history. After a summer of vigilantism 
that included four hangings, the committee turned to politics and formed the People's Party which dominated san Francisco's city government for the next decade. The 1856 committee is generally considered the great exemplar of American vigilantism and has received considerable attention from scholars.

San Francisco's 1856 vigilance committee regarded itself as a reorganization of that city's 1851 Committee of Vigilance. Like its more illustrious offspring, the 1851 committee hanged four men and banished many others. The vigilantes of 1851 did not, however, form a political party. Because of this some scholars have considered the work of the 1851 committee to be incomplete and have deemed it less worthy of attention than the committee of 1856. But in attempting to understand the intellectual grounding of san Francisco's vigilantes, this view is incorrect. The vigilantes in 1856 felt they were carrying on the work of the 1851 committee. Thus, to comprehend the events of 1856 it is necessary to understand the inspiration for the 1851 vigilance committee. The key to vigilantism in san Francisco lies in 1851.

An understanding of the spirit which animates vigilantism is valuable because of what it reveals about American concepts of self-government. Vigilantes conceive of their authority as springing from the same source as does that of the government: the people. San Francisco provides 
an extraordinary case for the study of notions about popular sovereignty in antebellum America.

In order to make sense of what happened in San Francisco in 1851 this thesis first analyzes the political thought and philosophy that had developed in America to that time. It also examines the changing social ethos that came to emphasize equality. The two vigilance committees of san Francisco were a consummation of the political and social devejopments of antebellum America. I have relied on the extensive secondary literature for my interpretation.

San Francisco in 1851 was in the midst of a singular episode in American history: the gold rush. The promise of riches made California the reification of the ideals of equality and opportunity that matured during the antebellum era. For the exploration of California and San Francisco I have used secondary sources and some primary sources, especially the Alta California, one of San Francisco's newspapers. This reliance on the Alta was in part due to its availability. The attitudes toward vigilantism expressed by the Alta were similar to other California newspapers. All of them supported the vigilantes in 1851. The episode of vigilantism in 1851 was a formative experience for the city of San Francisco. It served as an example of popular action and helped to define the limits of such action for the city's residents. The relationship between popular action and government was illuminated in san 
Francisco. Because of the way in which the people were endowed with power, they could create government and later defy that same government without destroying their creation. 


\section{TABLE OF CONTENTS}

CHAPTER

PAGE

I INTRODUCTION . . . . . . . . . . . . . . 1

TI ANTEBELLUM AMERICA: THE CONFIGURATION

OF A POPULAR SOCIAL ORDER • . • • • • • • • . 9

Popular Sovereignty and the

Social Contract... . . . . . . 10

The Development of Popular Sovereignty

in America. . . . . . . . . . . . 17

Labor, Equality, and Majoritarianism

in Antebellum America . . . . . . . 26

The Market Culture and

Social Control . . . . . . . . . 54

II GOLD RUSH CALIFORNIA: CHAOS AND COMMUNITY • • 62

Gold Rush California: The Setting . . . 65

Miners and Merchants . . . . . . 71

Social Control in the Mines: Lynching . 77

Middle Class Values in San Francisco . 80

Social Control in San Francisco . . . . 84

California Justice . . . . . . . . 93

IV SAN FRANCISCO: METROPOLIS OR MINING CAMP? . . 96

The Development of Government

in San Francisco. . . . . . . . . . 97

The Hounds Incident . . . . . . . 108

Ambivalence Toward Government

in San Francisco. . . . . . . . . . . 111 
V SAN FRANCISCO VIGILANTISM:

THE EXCITEMENT OF 1851 . . . . . . . . . . 117

Crime in San Francisco . . . . . . . 117

The Jansen Affair . . . . . . . . 120

The Chain Gang . . . . . . . . 122

Jail Breaks and Fires . . . . . . . 124

Outrage . . . . . . . . . . . . 129

Justifications for the

Vigilance Committee . . . . . . . 133

James Stuart . . . . . . . . . 147

A Collision with the Authorities . . . 154 Politics? . . . . . . . . . . 158

VI CONCLUSION . . . . . . . . . . . . 161 
CHAPTER I

\section{INTRODUCTION}

From 1856 until the mid-1860s the People's Party dominated San Francisco politics and government. It was a non-partisan movement, heavily influenced by the city's merchant class. Their motto was "No Party, No Creed, No Sectional Issues."1 What was remarkable about the party was not its membership or programs, but its genesis: it was born directly from the nation's largest organized vigilante movement. The organization's defiance of law was transmuted into legal authority. ${ }^{2}$

1 Quoted in Philip J. Ethington, "The Structures of Urban Political Life: Political Culture in San Francisco, 1850-1880" (Ph.D. diss., Stanford University, 1991), 138.

2 On the 1856 Committee of Vigilance Hubert Howe Bancroft, The Works of Hubert Howe Bancroft, vol. 37, Popular Tribunals, vol. 2, (San Francisco: The History Company Publishers, 1887), remains the best narraicive of the committee's activities. Ethington views the committee as a political movement and thus as an illustration of san Francisco's unique political culture. Other interpretations are offered by Robert M. Senkewicz, Vigilantes in Gold Rush San Francisco (Stanford, California: Stanford University Press, 1985); Roger W. Lotchin, San Francisco, 1846-1856, From Hamlet: to City (Iincoln, Nebraska and London:

University of Nebraska Press, 1974); Peter R. Decker, Fortunes and Failures: White Collar Mobility in NineteenthCentury San Francisco (Cambridge, Massachusetts and London: Harvard University Press, 1978); Richard Maxwell Brown, Strain of Violence: Historical Studies of American Violence and Vigilantism (New York: Oxford University Press, 1975), 
The 1856 Committee of Vigilance claimed it was responding to lawlessness, official corruption, and election fraud. Two killings stimulated the organization (really the reorganization) of the committee of vigilance. The shooting of U.S. Marshal William Richardson by gambler Charles Cora and that of blustering newspaper editor James King of William by Democratic political hack James Casey resurrected an earlier vigilance committee that had been active in 1851 .

In 1856 the vigilance committee enrolled some 8,000 citizens. They hanged four men (including Cora and Casey), deported more than two-dozen others, and took political control of San Francisco. Richard Maxwell Brown maintains that the 1856 committee "had much to do with creating the favorable image of American vigilantism in the nineteenth century."3 Vigilantism turned into a political and cultural triumph.

Scholars have concentrated on the committee of 1856. It was, after all, the largest vigilante movement in

all of whom emphasize the vigilance committee's mercantile leadership and nativism in their interpretations. Brown understands vigilantism as part of a pattern of violence in American culture. He considers the 1856 committee a "turning point in American vigilantism" from a frontier response to disorder to a "quest for solutions to the problems of a new urban America" (135). R. A. Burchell's, The San Francisco Irish, 1848-1880 (Berkeley and Los Angeles: University of California Press, 1980) is valuable in regard to nativism in San Francisco.

3 Brown, 135. 
American history. ${ }^{4}$ But in their eagerness to focus on San Francisco in 1856 they have too often skimmed over the events in San Francisco in 1851. In that year the original, albeit much smaller, śa urancisco committee exercised power in the emporium of the Pavific. Historians have failed to examine completely and carefully the milieu in which the 1851 vigilance committee formed and the inescapable conclusion that the 1851 committee was a necessary antecedent to the formation of the 1856 committee. The 1856 committee was but a reorganization of the earlier committee. The professed aim of the 1851 committee, to rid the city of an organization of criminals which they thought infested it, met with public approbation. The 1851 committee served the city as a symbol of public spirited men joined together to pursue the common good. The vigilantes of 1856 cloaked themselves in this image of civic dedication. The keys to understanding the adoption of vigilantism in San Francisco must be traced to 1851 .

The 1851 committee was a product of gold rush California. Like its more impressive offspring, the committee was driven by a desire to impose social order. The vigilantes' vision of social order was based on the values of the American middle class that emerged as a powerful force in the culture engendered by the nineteenthcentury market economy. But at the height of the gold rush

4 Brown, 135. 
in 1851, San Francisco was hardly a model of middle class propriety. And not all the vigilantes in 1851 were ready to accept the political duties inherent in enforcing order in a conventional manner, through politics and legal mechanisms. It was not until 1856 that vigilantism culminated in an effective political organization.

Organized vigilantism like that in San Francisco sheds light on a concept fundamental to the political culture of the United States: popular sovereignty. The belief that social and political authority rests in citizens, not government, legitimated -- powerfully and ironically -extralegal action for San Franciscans.

Popular sovereignty is a malleable concept. In its unadulterated form it atomizes political power. According to this presumption the sum of political power in the polity is divided and an equal part apportioned to each member. Individuals join together to form powerful groups and those which hold the preponderance of the polity's power, or sovereignty, determine the course of the community. Political authority is intrinsic in each person, and this creates a keen sense of personal sovereignty, but groups dominate society.

Because the doctrine of popular sovereignty holds that ultimate authority rests in people, and not government, it places the formal institutions of government on an insecure foundation. The implication of the authority to make laws 
and governments is revolutionary. While unchecked government can turn into tyranny, unchecked popular sovereignty can degenerate into anarchy. Americans fear both and have never found a perfect balance between the two. Instead, there has historically been a recurring testing of the boundaries to governmental and popular action. Gold rush California provides us with the best examples of one strain of this probing of limits -- well-organized vigilantism.

We customarily identify popular action -- the physical manifestation of political power -- with voting, working for a campaign, and using words, written or spoken, to influence someone in the government or other voters. Our established governments are delineated by constitutions, and other laws, which limit not only what the government can do, but how citizens can influence government. Indeed, the federal Constitution contains no mechanism for its subversion. It does not recognize popular constituent sovereignty: the authority to create, alter, or destroy government. strikingly in this regard, after the traumatic experience of the Civil War the guarantees that appeared in many state constitutions, that the people could change their form of government at will, disappeared. But during the antebellum years a notion about the right of revolution was a substantial tenet of American ideology.

The moral imperative of popular sovereignty -- that 
the people will always determine the course of their government -- is an empty promise. Southern supporters of the Confederate States of America and the Rhode Island suffragists led by Thomas Dorr in 1842, discovered this. ${ }^{5}$ Righteous platitudes about self-government are a pathetic defense against the state's utilization of violence as a means of political control. Popular sovereignty means nothing without the willingness to physically implement it. This leads to the crux of the matter: is vigilantism, if popularly supported, a legitimate manifestation of popular sovereignty? The answer has to be yes.

Hubert Howe Bancroft maintained that "if the people are supreme, they cannot create a power superior to themselves and still remain supreme. They cannot bind themselves to one another in fetters so strong that all together, or the ruling majority, cannot instantly break them."6 of course the authentic fulfillment of popular sovereignty -- majority rule -- can be as despotic and violent as government repression. There is nothing inherently tolerant about popular government. And Americans never have become

5 On the Dorr Rebellion in Rhode Island in 1842 see George M. Dennison, The Dorr War: Republicanism on Trial, 1831-1861 (Lexington, Kentucky: The University Press of Kentucky, 1976); Patrick T. Conley, Democracy in Decline: Rhode Island's Constitutional Development, 1776-1841 (Providence: Rhode Island Historical Society, 1977); Marvin E. Gettleman, The Dorr Rebellion: A Study in American Radicalism, 1833-1849 (New York: Random House, 1973).

6 Bancroft, vol. 36, 22-23. 
reconciled to a truly popular form of government. ${ }^{7}$

Vigilantism does not recognize formal, legal limits on behavior. It is, by definition, defiant of government. As such, it represents the frightening side of popular sovereignty: physical force. But the vigilantes in San Francisco during the 1850 s were not out-of-controi mobs. (Though the crowd dynamic -- that people will take actions as part of a crowd that they would not were they alone -played a part in the events in 1851 and 1856.) They were well-organized and had their own constitutions. Only a few men were actually punished by the vigilance committees. The vigilantes placed limits on themselves.

The problematic aspects of popular sovereignty -- how the will of the people is determined, what limits, if any, are placed on the popular power, and what the relationship is between governmental authority and the original authority of the people -- are illuminated by an investigation into the events of the summer of 1851 in San Francisco. The results of this investigation do not always sustain popular sovereignty as the lofty and flawless process of government. Americans so often believe it to be. Nor do the results show that powerful, popular, illegal movements inevitably

\footnotetext{
7 Bancroft, revealing the pressures of the post-Civil War era in which he wrote, later amended his far reaching legitimation of vigilantism and popular sovereignty with an assertion of his devotion to the union. "I am by no means a secessionist," he wrote, the "federal alliance was made for life and is not subject to divorce." Bancroft, vol. 37, 677 .
} 
destabilize government. The insurrection in San Francisco during 1851 did not topple government. It was an important confrontation regarding the limits of popular action in the United states.

This thesis considers first how economic and political changes affected the development of popular sovereignty in antebellum America and the implications this held for social control. Next, we examine the context of gold rush California and the complexion the crude mining camps gave to it. Then, in chapter three it explains the attitudes of san Franciscans toward government and social control. Within the context established in the first three chapters, the final chapter looks into crime, the 1851 vigilance committee, and the ambivalent response of San Franciscans to vigilantism. 
CHAPTER II

\section{ANTEBELLUM AMERICA: THE CONFIGURATION \\ OF A POPULAR SOCIAL ORDER}

The vigilantes who seized power in San Francisco were not rejecting their political heritage, but acting it out. Americans in the 1850 s understood sovereignty as something that existed independent of government. Power was thought to be inherent in men, not institutions. The members of the polity -- those who were white, male, and of age -- were the primal source of authority. Although to twentieth century sensibilities this seems a narrow, exclusive conception of political participation, in the nineteenth century it was a radical and expansive concept of the politically empowered citizen. Those who qualified as citizens experienced an unparalleled and unprecedented political and social equality. This widespread political authority had serious implications for the enforcement of social order. It magnified group pressure to conform. Yet these same powerful and equal individuals surrendered tremendous power to their elected (and appointed) representatives. There was an internal inconsistency in American popular sovereignty as to whether power was exercised by the many or the few. To 
comprehend the meaning that popular sovereignty had for nineteenth century Americans in California, it is necessary to go back to the country's founding period.

POPULAR SOVEREIGNTY AND THE SOCIAL CONTRACT

In the eighteenth century David Hume was astonished at the ease with which "men resign their own sentiments and passions to those of their rulers."1 In a society which is based on popular sovereignty, such as the United States, it is all the more surprising that the people, the many, will submit to the few.

Part of the reason for this submission to the few is the difficulty of actually involving the many in the work of governance. It would be a formidable task to include all the enfranchised members of even a small community in every decision. But there is a darker reason behind the reluctance to empower the people to exercise authority without someone or some mechanism to mediate that power. It is the fear that large groups of people often act in a dangerous and ungovernable ways. It is dreaded that individuals, under the influence of a crowd, will cast off their roles as citizens and become the thoughtless appendages of an uncontrollable mob. Iridividual governors

1 Quoted in Edmund $S$. Morgan, Inventing the People: The Rise of Popular Sovereignty in England and America (New York and London: W.W. Norton and Company, 1988), 13 . 
can be held accountable, mobs cannot be.

Vigilantism, because it is not an exercise of power through formally organized procedures, necessarily approximates mob behavior and for this reason is often feared. Vigilantism appears as an uncontrollable phenomenon. Yet vigilantes, when they act with popular approval -- as those in San Francisco -- can also seem to be a direct embodiment of the people's will. Vigilantism thus exposes a paradox within popular sovereignty: how can power be exercised in a restrained fashion (i.e. through formal procedures) and the people still retain a real sovereign authority over government?

John Locke's theory of the social contract assumes that individuals are free and equal in a state of nature. In joining together in society, through government, they give up some of their liberty in return for security. ${ }^{2}$ Individual freedom is checked by agreed upon standards of conduct. But unfettered majority rule nullifies the security the social contract promises to provide. Strong groups can subjugate minorities or individuals. Without restraints, popular sovereignty only institutionalizes brute force.

What, then, are the limits on popular action? The easy

2 I follow Joyce Appleby on Locke. See her Capjtalism and a New Social order: The Republican Vision of the 1790s (New York and London: New York University Press, 1984), 20-21. 
answer is that such limits can be institutionalized in government through law. But Americans have resisted surrendering sovereignty to government. The development of popular sovereignty in America is important because it conceived of government (and law) as being directly sanctioned by the people. With this conception of popular sovereignty law and government can only derive power from the people; they cannot stand on their own authority. This view of sovereignty obscured the difference between legal and popular action -- that is, the difference between the authority that empowers government to act and that with which the people are endowed.

The bromide that the United States is a nation of laws, not men, reveals a real, and warranted, fear about the implications of popular government. Only consensus can really restrain the populace. When original sovereignty is invested in the people, the durability of such a consensus bscomes problematic. Conventions and propriety are all that ultimately stand between civil order and civil war. The United States, in its Revolution of 1776, was literally created by physical force. That force was justified on the grounds of its popular basis. According to this creed the people have the right to alter or abolish government when it no longer suits their needs. Unless the existing government goes quietly (which experience suggests is unlikely) then the conflict will likely turn violent. One implication of 
popular sovereignty is, thus, an extraordinarily unstable society .

To deal with this inherent instability in their form of government, Americans have emphasized common standards of conduct. Any society must blend individual expectations into group expectations to achieve a semblance of order. In America both individuals and groups (majorities or pluralities) are empowered: individuals through accepted notions about natural rights and groups through legal and physical means, which amount to either institutionalized or informal coercion. Americans have often seen government as a check on group coercion and as a protection of individual rights. However, when government appears to fail to do these things, Americans can turn to popular sovereignty. In this regard the doctrine of popular sovereignty endows the people, regardless of government action or inaction, with ultimate power and the right to exercise this power outside of government. It was this notion of a power that resides in the people, independent of government, that informed San Franciscans who turned to vigilantism in 1851.

The American tradition has exalted, in a paradoxical fashion, both the individual and the majority. In a similar way the legitimacy of the constituted authorities and the supreme political power of the people have each been affirmed. Though both of the written icons of the American tradition, the Constitution and the Declaration of 
Independence, affirm popular sovereignty, each document treats the concept differently. The Constitution understands popular sovereignty as interrelated with government; it needs government for expression. The Declaration comprehends the deeper, destructive power of popular sovereignty. Natural rights empower the people to do violence to government. At different times in American history these contradictions have been exposed. In the process fundamental elements of the American political tradition have been laid bare. In San Francisco in 1851 vigilantes revolted against government, but ironically did not try to destroy government.

The conflict between individual rights and majority rule has been accommodated within the American political system, though not without serious, and sometimes deadly, disagreement. It has been more problematic how direct challenges by the people to the legitimacy of an established government could be contained within the existing political system. This dualism in American thinking has been informed by the Constitution's promise of stability and the Declaration's revolutionary creed. On the one hand, Americans have faith in the perfection of our republican or democratic form of government. But this "perfect" form of government rests on an unstable foundation: popular sovereignty. The durability of government depends on the whims of a sovereign people. What happens when the 
government and the people, each claiming to be the legitimate repository of authority, confront each other?

It was the possibility or probability of such collisions that convinced European critics of the newly founded United States that its political system, based on popular sovereignty, was inherently unstable. They believed that the masses would submit only temporarily, if at all, to government authority. The experience of the United States has not borne this out, however. Access to political power has enlarged over time. An ever-increasing political inclusiveness has disposed more and more people to feel a personal stake in the legitimacy of this form of government. A conviction on the part of the people that government is the highest expression of popular sovereignty (regardless of whether this conviction is true, false, or problematic) subdued, for the most part, the destructive aspects of popular sovereignty. American political culture has strengthened itself through an ability to harness a revolutionary doctrine to government.

This consensus about existing governments strengthened them: they had (presumably) been entrusted with power through popular means. Additionally, their very existence gave them access to political authority and accustomed citizens to their presence and exercise of that authority. The durability of American governments, at all levels, has largely rested on these bases. This is not to imply that 
there have not been serious conflicts between the authorities and the people in the United States. It would be surprising, given the American faith in popular sovereignty, if such conflicts did not arise. What has been astonishing is the ability of Americans, when faced with a contest between people and government, to insist upon the authority of both. Groups of Americans have occasionally been able to assert popular authority (in the face of duly established civil authorities) based on the Revolutionary doctrines embodied in the Declaration of Independence without repudiating the political system that produced the government they were defying.

In 1851 San Francisco vigilantes successfully challenged existing and popularly elected governments (both state and local) and but did not attempt to undermine or overthrow them. The vigilance committee simply supplanted the authorities in certain situations temporarily. An organization that can best be described as "middle class," openly defied government.

The role of a distinctly American notion of popular sovereignty in instances of vigilantism has not been adequately examined. It was this notion, along with the circumstances of gold rush California, that furnished the impetus for the 1851 vigilance committee.

The 1851 vigilance committee was a part of a series of manifestations of San Francisco's political and social life 
and was not separate from the city's usual existence. Nor was it isolated from American traditions. The committee provides valuable insights into how the sovereign people exercise their will and what limits, if any, exist to restrict their action.

THE DEVELOPMENT OF POPULAR SOVEREIGNTY IN AMERICA

In theory popular sovereignty derives its authority from God or nature. Self-government is considered to be the natural order of things. But in a practical sense it relies on consensus or violence (or coercion) for its authority. Sovereignty, in order to be effective, requires an agreement about its legitimacy. Part of the potency of American popular sovereignty is that its inclusiveness has strengthened a consensus about the political system. The less attractive source of power is the coercive and potentially violent capacity of an effective majority. Authority assumes a just claim to the use of coercion or violence in order to carry out the sovereign will. A powerful consensus about the morality of popular government has helped keep violence partially submerged in American political life. When large groups exert their sovereignty in a physical manner, the appropriate response of the 
government and other citizens is not always clear. ${ }^{3}$

This tension between intellectual and physical sovereignity is real in the United States because of the manner in which popular sovereignty developed there. Americans claim both of these phases of sovereignty. Americans also assume rights to both political types of popular sovereignty: the legislative power and the constituent power, the one being the power to make laws and the other the power to make governments. This was a sharp break with the English roots of American government. As Edmund Morgan has noted, England never did achieve "a formulation and establishment of its constitution by a popular sanction or authority separate from its government." 4 Parliament exercised popular sovereignty in

3 The most obvious example is the American Civil War. The forcible repatriation of the Southern states was a repudiation of popular sovereignty. Another striking example is the Dorr Rebellion in Rhode Island in 1842. The state's existing government refused to recognize a popularly ratified constitution which would have instituted a new state government. The rebellion was forcibly suppressed. A case which resulted from the rebellion came before the United States Supreme Court. In Luther v. Borden the court made clear that it would not enforce the exercise of constituent sovereignty. The implication was that the establishment of new governments, even if popularly supported, would have to be achieved through violence. See George M. Dennison, The Dorr War: Republicanism on Trial, 1831-1861 (Lexington, Kentucky: The University Fress of Kentucky, 1976); Patrick T. Conley, Democracy in Decline: Rhode Island's Constitutional Development, 1776-1841 (Providence: Rhode Island Historical Society, 1977); Marvin E. Gettleman, The Dorr Rebellion: A Study in American Radicalism, $1833-1849$ (New York: Random House, 1973). 
England. In the United States, conversely, a popular sanction separate from the government exercised the constituent power that created the nation.

Part of the reason for this difference between England and the United States is the oft-noted fact that the latter had a very definite historical past. Even the colonial experience was not particularly distant to antebellum Americans. The first permanent settlement, at Jamestown, dated only to 1607. The claim of Americans to be a distinct and independent people was even more recent: 1776. This independent people had constituted its own national government by 1789. There was, in contrast to England, nothing mysterious about the role of the people in creating their government in America. The people had presented themselves in a physical way and exercised their constituent power. Because of the temporal limits on the American experience, Americans had access to the origins of their government.

While the creation of the American nation was informed by a broad range of ideological and practical concepts, 5 it

5 The literature on the ideology of the founding is extensive. Indispensable is Gordon S. Wood, Creation of the American Republic, 1776-1787 (New York: W.W. Norton, 1972). Some useful journal articles are Isaac Kramnick, "The 'Great National Discussion': The Discourse of Politics in 1787," William and Mary Quarterly 45 (January 1988), 3-32; Richard C. Sinopoli, "Liberalism, Republicanism and the Constitution," Polity 19, no. 3 (1987), 331-352; Joyce Appleby, "Republicanism in Old and New Contexts," William and Mary Quarterly 43 (January 1986), 20-34; Peter S. Onuf, "Reflections on the Founding: Constitutional Historiography 
was firmly grounded in the belief that government was created by an agreement (or contract) among men. This liberal view saw society as composed of equal individuals with diverse interests and conceptions of good. The community presupposed the individual. Rooted in Lockean views of men as naturally equal and possessing liberty in their natural state, individuals agreed to society for reasons of security. This security gave them independence to pursue their own chosen aims. Regulation of individuals was justified only insofar as they had freely given up a portion of their natural liberty. Citizens achieved virtue in a private and individual sense. Industry and frugality were the foremost virtues. In this way liberalism exalted individual commercial activity as evidence of these virtues. ${ }^{3}$

in Bicentennial Perspective," William and Mary Quarterly 46 (April 1989), 341-375. This list is by no means exhaustive but only suggestive on some recent scholarship on interpretations of the founding period.

6 Clearly I reject the arguments of the republican revisionists who argue that classical thought most heavily influenced the founding generation. On the role of classical thought see wood, especially 46-123; J.G.A. Pocock, The Machiavellian Moment: Florentine Political Thought and the Atlantic Republican Tradition (Princeton: Princeton University Press, 1975) and, with Terence Ball, Conceptual Change and the Constitution (Lawrence, Kansas: University Press of Kansas, 1988); Bernard Bailyn, The Ideological Origins of the American Revolution (Cambridge, Massachusetts: Harvard University Press, 1967); Robert E. Shalhope, "Toward a Republican Synthesis: The Emergence of an Understanding of Republicanism in American Historiography," William and Mary Quarterly, 29 (January 1972), 49-80. The dominating influence of Locke on the founders was widely accepted until the emergence of the 
It would be wrong to characterize Americans of the 1770 s and 1780 s as being in a Lockean state of nature. There were established communities: towns, counties, and states. There was also a commonality in the acceptance of institutions such as representative government and private property. But the Declaration of Independence and the Constitution provided examples of the construction of a new, national community. Both documents explicitly recognized and celebrated the American people as the only legitimate source of power to make a government.

Yet it would also be wrong to discount the sense Americans had of being relatively close to a state of nature. They were not savages, to be sure. But they perceived the land they inhabited as untamed; the hinterlands seemed to be in a state of nature promising rich

revisionist school in the 1960s. For examples see Carl Becker, The Declaration of Independence: A Study in the History of Political Ideas (New York: Random House, 1922, repr. 1942) and Louis Hartz, The Liberal Tradition in America (New York: Harcourt, Brace, 1955). Locke and liberalism have been resurrected recently. Thomas L. Pangle in his The Spirit of Modern Republicanism: The Moral Vision of the American Founders and the Philosophy of Locke (Chicago and London: The University of Chicago Press, 1988) sees his task as "reanimating" the role Locke's philosophy played in the thinking of the founders (p. 3). More accessible works are Joyce Appleby, Capitalism and a New Social Order: The Republican Vision of the 1790s (New York and London: New York University Press, 1984) and Isaac Kramnick, Republicanism and Bourgeois Radicalism: Political Ideology in Late Eighteenth-Century England and America (Ithaca and London: Cornell University Press, 1990). Both emphasize the role that commercial relations played in American thought. I follow Kramnick most closely in this chapter. 
rewards to those who could master it. Citizens experienced an equality unrivaled in the world. They had always had a hand in governing themselves.

In declaring their independence from England Americans made clear that sovereignty was a natural function of the people. When "one people" decided to change the way in which they were governed they were justified by "the Laws of Nature and Nature's God." According to the Lockean contract theory, men in a state of nature gave up a portion of their natural rights in order to be more secure. They could thus pursue their own chosen aims without many of the uncertainties and fears inherent in an anarchic state of nature. According to the revolutionary Declaration of Independence government had to derive its "just Powers from the consent of the governed." The people could change their government at any time to that form which "shall seem most likely to effect their safety and Happiness." This suggested that men did not need to be in a state of nature to exercise their natural rights. They retained the authority to change or abolish government notwithstanding the establishment of government. 7

The Constitution, its ratification, and the government it created were a masterstroke in representational politics.

7 The language of the Declaration of Independence clearly conceives of a social contract legitimated by the natural rights of its parties. Kramnick finds that "Locke lurks behind its every phrase" (293). 
American nationalists boldly ignored the states (i.e. the existing communities and governments) and invited the People to "ordain and establish this Constitution for the United States of Ainerica." Popular sovereignty was the supreme source of power in the American nation and the source of the nation itself. Proponents of the Constitution circumvented the state legislatures and held popular ratifying conventions. In this way the people approved in a straightforward, unmistakable manner of their government. They made their constitutions and they could unmake them. Thus all parts of the government represented the people. There had always been a distinction between the governed and the government. Now the distinction was blurred. The governed had made the government. ${ }^{8}$

Popular sovereignty, as understood in England, defined the people as composed of two bodies: the legislative power

8 My contention here is controversial; many scholars view the constitution as undemocratic (as did many of the document's contemporary opponents.) Charles A. Beard, An Economic Interpretation of the Constitution of the United States (New York: Free Press, London: Collier Macmillan, 1935), is the seminal work in this regard. More recently Gordon S. Wood has discussed the democratic character of the Constitution in "Democracy and the Constitution," Robert Goldwin and William Shambra, eds. How Democratic is the Constitution? (Washington, D.C.: A. E. P., 1980), 1-17. I rely on Wood for his argument that the proponents of the Constitution were successful in convincing (at least some) people that the mixed government of the Constitution was representative and thus "democratic." I go beyond Wood, however, in suggesting that the radical method of ratifying the Constitution - - the popular ratifying conventions -- gave Americans, up to the Civil War, a direct connection with the creation of the nation's government. 
which they exercised through an elected representative system and the constituent power which had been exercised, presumably in a similar fashion, in the hazy past. Americans, in creating their national government, transformed "the people" in a revolutionary way. Here, the people were endowed with sovereignty by God (or Nature). And like God, (to paraphrase Edmund Morgan) they were omipresent, for in themselves they constituted the "body politic" over which they ruled. The constituent and legislative powers were joined in the body politic. These powers were exercised by the "body natural" of the people (again borrowing from Morgan). It had been real, living, identifiable people who had consented to the constitutional contract. 9 The people's sovereignty in America was both the theoretical power that gave legitimacy to governmental authority and physical power which could be exercised by a crowd ... or a mob.

But the Constitution, though created by popular sovereignty, institutionalized only legislative sovereignty, not constituent sovereignty. It provided mechanisms for creating laws and amending itself, but did not establish any procedure to change the form of government. Under the Constitution the people could not exercise constituent sovereignty (so long as the government resisted) without violence. Beyond the preamble the only hint of popular

9 Morgan, 78-93, the quote is from 17 . 
constituent sovereignty in the Constitution was the vague "guarantee" in Article IV, that each state would have a "Republican Form of Government." What a "Republican Form of Government" might be was not described. The enforceinent of this guarantee was defined as a function of the federal government, not the people. The Constitution's silence regarding constituent sovereignty thus highlighted the problem of creating stable governments, a problem basic to popular sovereignty. ${ }^{10}$ To wit, how could the people retain the constituent power and yet have confidence in the longevity of government?

If the Constitution was silent on the matter of the constituent power, Americans had the Declaration of Independence to provide a basis for, and serve as an emblem of, their sovereignty. It was the exercise of this power that explained why there was a United States of America. And they had very concrete examples of the exercise of the constituent power. They watched it in the establishment of state constitutions. In England the tension inherent in governments based on popular sovereignty -- that between the governing laws and the sovereign people -- remained submerged as the people could not and had not presented themselves in their "body natural" to create government. In

10 The Dorr Rebellion in Rhode Island and the case of Luther $v$. Borden which arose from it, illustrated this problem of popular sovereignty. See Dennison, 3-8, 141-192, and especially 195-205. 
America the tension was palpable. It was people, not laws, that created new governments as Americans tamed a wild continent. As Americans settled new lands and set up new governments they exercised their natural rights in subduing nature. In San Francisco in 1851 the men who joined together in the Committee of vigilance understood themselves in light of this heritage of popular sovereignty.

LABOR, EQUALITY, AND MAJORITARIANISM IN ANTEBELLUM AMERICA

Although San Francisco's vigilantes referred back to their nation's revolutionary heritage, the heritage to which they referred was one that had been re-shaped in dramatic ways before 1850 -- the period generally referred to as the "Age of Jackson." Americans' view of themselves was modified during the antebellum years of the nineteenth century. The market revolution and the development of increasingly democratic political beliefs combined to form a confident middle class. The values of the middle class were particularly well adapted to the powerful forces of the market. Between the end of the War of 1812 and 1850 , the American culture based on land gave way to a culture based more on the market. Participation in the impersonal market eroded social barriers and reinforced a sense of equality - among white men, at least. Equality, combined with the era's mass politics, seemed in some ways to fulfill the 
promise of popular sovereignty, that all would have a hand in government. ${ }^{11}$

After the discovery of gold along California's American River in 1848, the Americans who went there in search of a fortune carried with them the precepts and ideals that they inherited from the ideologically crucial Jacksonian era (1828-1836) and the dozen or so years that followed during which these assumptions became firmly embedded in American political culture. In these years the notions of labor and production were extended far beyond the agricultural constraints of eighteenth century America. A middle class consciousness enshrined commerce and the pursuit of wealth. ${ }^{12}$ Those who fell outside of the accepted mores

11 "Land and Market," the first chapter of Charles Sellers, The Market Revolution: Jacksonian America, 18151846 (New York and Oxford: The Oxford University Press, 1991), 3-33, is a first-rate summary of the change America had experienced by 1815. Steven Watts extends this period a bit to 1820 in The Republic Reborn: War and the Making of Liberal America, 1790-1820 (Baltimore and London: The Johns Hopkins University Press, 1987). For Watts this change "involved the consolidation of a market economy and society, a liberal political structure and ideology, and a bourgeois culture of self-controlled individuals" (xvii). Joyce Appleby finds the influences of the Atlantic trade and commercial agriculture of the eighteenth century as having inclined Americans toward a market-style culture before 1800. Gary B. Nash, in The Urban Crucible: Social Change, Political Consciousness, and the Origins of the American Revolution (Cambridge, Massachusetts and London: Harvard University Press, 1979), finds this change to a "commercial economy .... competitive social order ... and contentious civic life" beginning even earlier, in America's colonial cities (vii).

12 Richard Hofstadter's "Andrew Jackson and the Rise of Liberal Capitalism," in his The American Political Tradition and the Men who Made It (New York: Alfred A. 
were seen as a threat to the security of the community.

The shift of the Jackson years is evident in the way in which the conception of citizenry changed between 1800 and 1850. The United States of America was based on the proposition of government by the governed. During the early years of the republic, there were widely accepted notions about what type of men were best suited to self-government. The virtues of disinterestedness and independence were thought to be indispensable. For the republic to survive, citizens would have to actively take part in their communities. The best men should be selected to run the machine of government. ${ }^{13}$

The model citizen was the yeoman farmer. He depended on no one but himself for his livelihood. His ownership of land made his independence unassailable. The experience of Americans during the early national period from independence

Knopf, 1948), 44-66, is indispensable to a study of this period. His entrepreneurial "Jacksonian Man" deservedly remains a stock character in the era's history. Arthur M. Schlesinger, Jr. provides a counterpoint to Hofstadter in The Age of Jackson (Boston: Little, Brown and Company, 1945). Schlesinger viewed the Jacksonians as the champions of the laboring man. Marvin Meyers in The Jacksonian Persuasion: Politics and Belief (Stanford, California: Stanford University Press, 1957) found the Jacksonians full of paradox, advancing the changes and progress of a free market society while longing for the simple virtues that were thought to be rooted in the early republic.

13 See Gordon S. Wood, "Interests and Disinterestedness in the Making of the Constitution," Richard Beeman, Stephen Botein, and Edward C. Carter, eds., Beyond Confederation: Origins of the Constitution and American National Identity (Chapel Hill, North Carolina: University of North Carolina Press, 1987), 69-109. 
to about 1800 , lent much credibility to this ideal. Land ownership was widespread. There was an unprecedented equality in condition and opportunity -- among whites at least. This made it easy for many Americans to believe that they and their country could remain aloof from the intrigues and war of Europe. Indeed, with the slowness of communication it was easy to feel isolated, even from one's neighbors.

But the ideal was not reality. Not everyone owned property, and this made many property owners wary of the propertyless. Despite the remarkable equality, there were wide disparities in wealth and opportunity. Regardless of the sense of isolation, Americans did not live in a vacuum. Nor, it seems, did they want to do so.

Eastern merchants were concerned with shipping and credit. These were necessarily tangled in European affairs. Backcountry farmers in western Pennsylvania worried about continued access down the Mississippi River, controlled alternately by France and Spain and coveted by Britain. The states also had to contend with each other. In time, the Articles of Confederation were discarded in favor of the Constitution, which was more congenial to commerce. There were ongoing sectional disputes. Americans would have to contend with the world and each other.

The United States withstood many serious threats to its existence and emerged after the first quarter of the 
nineteenth century as a secure nation. It had immensely expanded its frontiers, primarily through the Louisiana Purchase. It had survived the War of 1812 with Britain. The war, often called the second war for American independence, provided Americans with a psychological boost. The end of the war, and especially Andrew Jackson's stunning victory at New Orleans, turned a divisive and unpopular war into a galvanizing experience. It made the United States feel more like a nation. ${ }^{14}$

Before the war the United States had largely been concerned with preserving its experiment in republican government from internal and external threats. The end of the war in 1815 saw the end of the Napoleonic wars in Europe. This stabilized the international situation and minimized external threats to the country and its republicanism. Americans were able to concentrate on activities at home. While they remained concerned about internal threats to republicanism, American confidence regarding their form of government increased. Republicanism was no longer an experiment but a proven form of government. ${ }^{15}$

Americans were confirming for themselves, if not the world, that their system was superior to all others. They

14 On the War of 1812 and its relation to the rise of a market society see Watts, 276-321.

15 Ibjd., 283-284, 287. 
found unimpeachable evidence in the unprecedented growth of their young nation. They flowed into the area of the Louisiana Purchase and soon moved beyond it. This geographic expansion coincided with the larger developments of modern nationalism and the international market economy.

The context in which Americans experienced these developments was one that exalted the values of liberty and, increasingly, equality. To Americans it was obvious that self-government, improvement, and progress were bound together. They found ready outlets for their national pride and economic desires in the developments of nationalism and capitalism.

The vast natural resources and a rapidly growing population were superbly adapted by the nation's culture and political system to the market revolution. The nation's success seemed to stem from its alignment with the natural order of things. Even with periodic and sometimes severe economic downturns, the economy surged ahead. Americans experienced not slow and steady improvement, but an explosion. ${ }^{16}$ They considered their country an archetype of political perfection. To its faithful, the American system was viewed as bringing about a secular millennium of prosperity and political freedom. ${ }^{17}$

Americans' optimism was reflected in their culture. To

16 Sellers, 22-23, 132, 343-345, 391-392.

17 I am borrowing frum sellers, 301. 
be American was to expect freedom and progress as a birthright. But this progress forced Americans to rethink how they fit into the community and to adapt to a rapidly changing world. Setbacks or even a lack of advancement were magnified by this fundamental expectation of progress. The post-war era witnessed an international market largely unimpeded by European conflict. The United States, with its vast tracts of agricultural land, continued to expand its output of produce. The international market for cotton typified a market pressure that was changing agriculture. This was the pressure for specialization in commercial crops. The widening economy allowed and often encouraged the production of a single crop for trade rather than the cultivation of a variety of crops for subsistence. The urbanization that took place also encouraged specialization by providing domestic markets for produce. The role of the farmer in America was beginning, albeit slowly, to change from the independent and isolated yeoman to the interdependent participant in a market economy. He was taking on some of the characteristics of the wage earner. ${ }^{18}$

A similar change was taking place in the cities. The system of independent masters as the nation's producers of non-agricultural products was also affected by the

18 Harry L. Watson, Liberty and Power: The Politics of Jacksonian America (New York: Hill and Wang, 1990), 19-20, 28 . 
increasing pervasiveness of the market economy. The pattern of progression from apprentice to journeyman to master had been part of the social fabric of the city. The master artisan was like the yeoman farmer: possessed of skills, tools, and shop, he was an independent and esteemed member of the community. They were respected and acted as leaders in urban politics. Their place was elevated above that of the journeyman and apprentice as was the freeholder's above the propertyless. Access to more and larger markets changed this social order. ${ }^{19}$

The increasing division of labor in the urban work force changed expectations but also created new opportunities. Instead of the single track of apprentice to journeyman to master, the new increasingly market-driven economy needed other roles to be filled. Industries needed foremen, bookkeepers, clerks, superintendents, engineers, and managers, and the services of lawyers, doctors, ministers, and teachers. Harry watson has noted that these new career opportunities created by urban growth "laid the basis of a solid middle class." This solid middle class, well-adapted to the market culture, increasingly fixed the standards by which members of society were measured. ${ }^{20}$

The nature of the American experience had irretrievably changed. People who in the past had been isolated from one

19 Ibid., 29-31; Sellers, 24-25.

20 Watson, 31-32, 178-179; Sellers, 237 . 
another were now linked by newspapers, roads, market relations, and, increasingly, by a new similarity of condition: wage labor. What had been an insulated, evenly-paced society was becoming faster-paced and interdependent. Technological and market changes combined with foreign and internal immigration to produce a shifting experience for Americans. The ideas and conditions produced by the vicissitudes of American society were widely reported in the popular press, thus providing a connection among a diverse citizenry.

The market revolution drastically changed the world in which Americans lived. Its various manifestations combined to form a new order. The accelerating pace of industrialization demanded cotton for mills and other products and the population became increasingly urbanized. The transportation revolution was instrumental in making markets accessible. Both industry and commercial agriculture relied on innovations in transportation to profitably reach their markets. Roads, canals, steamboats, and later railroads shrank the distance between producer and market. ${ }^{21}$

The changes in transportation also changed the nature of communications. The number of post offices increased and rates went down. Steamboats and railroads operated on

21 George Rogers Taylor, The Transportation

Revolution, 1815-1860 (New York: Rinehart, 1951); Watson, 24-28; Sellers, 41-44. 
increasingly reliable schedules. The telegraph sped messages across long distances. The invention of the rotary steam press in 1830 , along with these improvements in transportation, gave rise to the inexpensive, mass-circulation newspaper. This made communication with distant markets more regular and business-like. Such interaction, through letters, newspapers, and magazines, became a feature of daily life. The American Tract Society and the American Temperance Society spread middle class values effectively with the help of cheap printing. America was becoming a mass market with a mass culture due to the increasing ease of communication. ${ }^{22}$

Americans were changing from independent yeomen and craftsmen to interdependent economic actors. They made decisions in light of market forces, mainly profit. Improvements in transportation and communication allowed them to take part in this larger market.

These larger and more profitable markets engendered a larger scale of production. In a small market the handcrafts of the master artisan ably filled the local community's needs. But with access to mass markets the production of large amounts of identical products became a profitable possibility. The capitalist could anticipate these markets and produce large amounts of a product (with the corresponding benefits of economies of scale) with the

22 Watson, 26-27, 89, 223; Sellers, 263-264, 370-372. 
employment of piece-workers or wage laborers. The master, without sufficient capital, could not compete. Accordingly more workers were employed as wage laborers by the increasingly successful capitalists. Under the old system the apprentice hoped to rise to become his own master. Under the wage system the worker had only dim hopes of becoming a capitalist. But the proportional increase in wage earners helped incubate new ideas about political and social equality; an equality that did not depend on land ownership but was inherent in men. ${ }^{23}$

Changes in the way people earned a living significantly affected political relations. The American body politic had been made up of men who were equal because of the shared condition of property ownership. Though property ownership remained prevalent, the portion of those without property or with little hope of owning property (or the means of production as masters), especially in the cities, had increased. This caused a rethinking of how equality was achieved. This was part of what Charles Sellers has identified as a change from a culture of land to a market culture. ${ }^{24}$ One result of the changing attitude toward land was the political empowerment of propertyless wage laborers.

23 Essential to study of urban labor in America is Sean Wilentz, Chants Democratic: New York City and the Rise of the American Working Class, 1788-1850 (New York and Oxford: Oxford University Press, 1984). On the masterjourneyman-apprentice system see 23-60; Watson, 29-31.

24 Sellers, 6 . 
This empowerment was essential to the ascendance of mass politics.

The change in the perception of equality was part of the development of an American self-image, particularly among the faithful of the Democratic Party. As America's future no longer seemed in doubt, the sense of the republican "experiment" gave way to a sense of accomplishment. Economic, geographic, and population growth, coupled with unrivaled personal freedom, demonstrated to Americans the indisputable correctness of their form of popular government. Democracy came to be equated with progress. When combined with an increasing sense of nationalism, it produced a new image of the patriotic American. Though the freeholder remained at the pinnacle of the American pantheon, there was an increasing sense that the rights of man were separate from, and superior to, the rights of property. This had profound implications for American politics, as Watson explains: "If one white man was as good as another, then simple majority rule would be a safer source of virtue and a more reliable guide to the common good than the paternal benevolence of a few well-trained and high-minded gentlemen."25 Political power was becoming more accessible. In the antebellum era many states recognized the benefits of tying landless laborers to the government by 
offering them the vote. Residency, rather than property ownership, increasingly became the standard which determined the eligibility to vote. For example, the continued elevation of property over natural equality was questioned by the landless citizens of Richmond, Virginia in a petition in 1829: "Attachment to property, often a sordid sentiment, is not to be confounded with the sacred flame of patriotism." 26

It is not surprising that Americans moved away from property ownership as a measure of equality. The American tradition comprehended the ideals of virtue, disinterestedness, and independence. An industrious but landless laborer could be virtuous and disinterested, if not as independent as a yeoman. The labor theory of value -the principle that all wealth is produced by labor -- gained credence in antebellum America among a broad portion of the population. This wide spectrum of support was due to the varying definitions which labor could encompass. ${ }^{27}$

As land ownership began to be less important as a measure of political rights, the definition of citizen (or patriot) was changing. It was loyalty to the national culture and a consciousness of being part of that culture that defined a citizen or an "American." It was becoming less his independence and separation from his fellows (like
26 Ibid., 50 .
27 Wilentz, 157-158. 
the hardy yeoman), but his status as a productive and dedicated part of the nation that demonstrated his citizenship. ${ }^{28}$

The traditional view of a political elite of wealth (property ownership), talent, and intellect assumed the existence of political inequality. The stake-in-society theory assumed that as a primary function of government was to provide security for property, that only those who owned real property had a "stake" or interest in the maintenance of society. Thus property owners were the only safe repository for political power; the propertyless would only use it to seize others' property. This theory circumscribed popular sovereignty by limiting its extension to those who met an artificial standard of property ownership. Men might be naturally equal, but society was not a natural state. The apportionment of political power, it was thought, should take into account the acquired differences among men.

However, the operation and success of American society with its representative government and relative equality of conditions eroded political traditions. Ashworth asserts that "Orthodox Democrats invariably rejected the traditional stake-in-society theory upon which so much of American

28 John Ashworth, 'Agrarians and Aristocrats': Party Ideology in the United States, 1837-1846 (Atlantic Highlands, New Jersey: Humanities Press Inc.; London: Royal Historical Society, 1983), 12. 
republicanism had been based."29 If the stake-in-society theory was discarded, it meant that distribution of political power would come to reflect men's natural equality; sovereignty would be more widely and evenly distributed. The changes in American economic life wrought by the market revolution had helped change political ideas about equality.

Democrats transformed the stake-in-society theory. They elevated the rights of man to a place separate from and superior to the rights of property. Liberty and equality were functions of a natural process, not of the artifice of property ownership. Men were capable of self-government because they were men, not because they owned property. Men's liberty and equality and their desire to preserve them gave them a stake in society. This new and broader conception of equality signified a wider and more popular base for sovereign authority. 30

Property ownership remained an important part of the American ideal, however. Americans either owned, or hoped to own, property. The Democrats lionized the ideal of the yeoman farmer. But their belief in political equality undermined their rhetoric of the agrarian hero. If lack of property did not exclude one from the realm of politics, then it would be increasingly difficult to isolate the
29 Ibid.
30 Ibid., 23-28. 
property-owning farmer as the repository of the nation's virtue. 31

More and more it would be a man's labor and not the type of labor that would make him respectable and give him a claim to political equality. Ashworth cites the "commendable qualities" such as "steadiness, simplicity, frugality, sternness, and endurance" that were the hallmarks of all productive labor. Labor was the moral basis of the economy. ${ }^{32}$ Those who had and utilized these "commendable qualities," it was believed, were rewarded with material success. If economic opportunity was open to all, this implied that political and social authority were similarly available. ${ }^{33}$

By the 1830s Americans no longer thought of their country as a republican experiment in self-government, but as a symbol of its triumph. As self-government proved to Americans that it was the best form of government, they increasingiy viewed its success as a natural phenomenon. Its efficacy stemmed from the natural order, not from man-made systems. Thus it was logical to do away with a man-made custom (property ownership qualifications) and revert to a natural principle of equality among men. ${ }^{34}$

$\begin{array}{ll}31 & \text { Ibid., 22-25. } \\ 32 & \text { Ibid., 23. } \\ 33 & \text { Sellers, 27-33. } \\ 34 & \text { Ibid., } 70\end{array}$


The Jacksonian Democrats embraced the ideals of equality and the fundamental goodness of self-government. They believed that democracy developed the moral and physical resources of Americans. All the nation's triumphs reflected on democracy. Democracy and nationalism were united in the Democratic mind. It had been the achievement of Americans to overturn and prove wrong the political theories of the rest of the world. The incredibly rapid development of the United States was positive proof of the virtue of the democratic system. ${ }^{35}$

Democracy and progress became an identity. Progress flowed naturally from obedience to the natural law of self-government. George Bancroft enunciated this principle when he wrote: "truth is a social spirit; her home is in the heart of the people ... [by giving] power to the whole people ... you gain the nearest expression of the law of God, the voice of conscience, the oracle of universal reason."36 Americans were stripping away the man-made limitations to the extension of political authority to reveal a political order based on unrefined principles. Paradoxically, as their society matured, Americans' conception of political organization was moving back toward a state of nature.

In theory, the physical isolation of the yeoman had

35 Ibid., Ashworth, 7-9.

36 Quoted in Ashworth, 10. 
forced him to be self-reliant; he had to work in order to survive. Dependent only on himself his virtue and independence were assured. But urban laborers also depended on their own labor for survival. That they did not own the means of production as the yeoman did became only incidental. The yeoman might continue to be idealized, but every laborer could lay claim to the same commendable qualities that were produced by the sweat of one's brow, whether on the farm or in the shop. In the largely rural society of antebellum America, it would have been surprising if the farmer was not the symbol of equality and virtue. More and more, however, platitudes about virtue were directed at labor, significantly so.

Many Democrats believed in a labor theory of value. Wealth was produced by labor. Liberty was a function of the ability to enjoy the rewards of one's labor. Individuals or minorities that could appropriate the rewards of others' labor would have power over the others. With such power the few could destroy others' liberty and social equality along with it. Liberty, equality, and power were, then, rooted in labor. The ability to labor was universal, and thus this avenue to liberty, equality, and power was open to all. Ashworth found the consequences of this to be momentous for American politics: "A political system that was explicitly and avowedly based upon the qualities common to all men -- 
this was the levelling thrust of Jacksonian Democracy."37

Democrats sought to have power distributed amongst the individual members of society. Men felt the effects of government equally and thus should share equally in it. Democracy was then a vehicle for the expression of the public will. The link between the holders of power (individuals) and the employment of that power (government) should be a direct relationship. There should be no intervention by an elite, natural or otherwise, between the public will and government action. For most of the Founders such an unmediated process had been frightening because it failed to restrain that antithesis of virtue: self-interest. Democrats, however, recognized and accepted the role of self-interest in society. 39

The desire for wealth and power were universal propensities. Even those with great integrity were not considered immune to them. Ashworth argues that "the Democratic view of man was essentially ambivalent and dualistic, for while the ordinary man was naturally good and virtuous he was also potentially greedy and grasping."39 Instead of attempting to subdue self-interest, Democrats capitalized on it to strengthen democracy.

Jacksonians thought self-interest to be dangerous only
37 Ibid., 20, 23.
38 Ibid., 24, 35-36.
39 Ibid., 16-18. 
when it was exercised by an individual or a minority. In these cases self-interest would work against the community's interest. But should the combined self-interest of the majority be aroused, it would benefit the community. To the Democratic mind, majorities could not subsist on minorities and their struggle against minorities that grasped for wealth or power was only defensive. History was believed to have shown that the majority, the masses, had a]ways struggled against the powerful few to protect their liberty or property. ${ }^{40}$ Andrew Jackson, for example, maintained "never for a moment believe that the great body of the citizens ... can deliberately intend to do wrong."41

The Founders had articulated assumptions about the people's right to assent to and participate in government. However, they felt that a careful selection process was necessary to the success of republican government. This was evidenced by their reliance on the selection of senators by state legislatures and the president by the electoral college. It was also reflected in the power given to the national government, which presumably would be less subject to the vagaries of direct democracy. To the contrary, a generation later the Jacksonians took self-government much more literally.

The aggrandizement of the common man and the sanction

40 Ibid., 18-20.

41 Quoted in Watson, 10 . 
of mass politics in the 1830 s and 1840 s, had the effect of validating the undistinguished. Alexis de Tocqueville's well-known remark about the "equality of conditions" seemed to refer to the passable condition of most Americans. Tocqueville found that a "middling standard" prevailed in everything in America. 42 The "middling standard" intellectually simplified political equality. There was dignity in being ordinary.

Men were thus encouraged to conform. Ironically this increased their sense of self-importance. There was a symbiotic relationship between individualism and the faith in the majority. Equal individuals were necessary to legitimize majority rule. Majority rule gave even the most insignificant man, in the abstract and sometimes the real sense, power equal to other men. The broadening of political power through universal manhood suffrage and the equality that accompanied this extension of political power loosened the restraint that deferential politics had enforced. 43 As more men participated on increasingly equal terms in the political process, there was a more direct connection between majority rule and the exercise of government authority.

The equality of the market-oriented economy rewarded

42 Quoted in Ibid., 33.

43 On deference in early American politics see Morgan, $169-173,286,292,300-301$; Nash, 98-100, 129, 200-201. 
commercial self-interest. Grit, determination, and persistence, abilities accessible to all, were valued over talent. "Above all," Watson concludes, "the Jacksonians" celebration of the rights of the common man had encouraged the belief that individual self-improvement was the supreme goal of American society. "44

Richard Hofstadter, in his well known essay on antebellum American politics, identified as central the "Jacksonian man" who was characterized by his adaptation to the new market economy. In the antebellum period the "typical American," for Hofstadter, "was an expectant capitalist, a hardworking, ambitious person for whom enterprise was a kird of religion, and everywhere he found conditions that encouraged him to extend himself." 45 Edward Pessen offered a more prosaic evaluation of Americans: "Materialism and a love of money were perhaps their most noticeable traits."46 Both Hofstadter and Pessen are on target; upward mobility was the great motive of antebellum America. And nowhere in antebellum America were the prospects for rapid advancement as dramatic, and real, as in the rich placers of California.

With everyone (who was white and male, at least)

44 Ibid., 252.

45 Hofstadter, 55-56.

46 Edward Pessen, Jacksonian America: Society, Personality, and Politics (Homewood, Illinois: The Dorsey Press, 1969), 349 . 
possessing liberty and equality, there was a great deal of pressure on individuals to succeed. The freedom and opportunity that was widely available in the United States, at least as an ideal, lent a sense of urgency to getting ahead. The tremendous amount of internal immigration testified to Americans penchant for seeking new opportunities. Americans still idealized the producer ethic, but the bustling pace, especially in urban areas, made slow, steady improvement seem like no improvement at all. Upward mobility was not just a possibility, but an imperative. In 1836 Francis J. Grund, an immigrant, captured this American disposition when he compared the country to a "gigantic workshop" with a warning over the entrance, "No admission here, except on business."47

This striving for material gain impressed foreign visitors to the United States. They were struck by the bustle and movement in America. Francis Lieber, for example, thought that "an American distinguishes himself ... by a restlessness, a striving and driving onward. [He] wants to perform within a year what others do within a much longer period." 48

The economic and political changes effectively altered the way individuals perceived themselves. Political equality and economic opportunity combined with the notion

47 Quoted in Hofstadter, 56.

48 Quoted in Pessen, 22. 
of self-improvement to exalt aspirations for upward mobility over the steady and isolated existence of the agrarian producer.

The allure of the success ethic and its rewards supplanted the deprivation of the producer ethic. The producer ethic's hardy yeoman remained a respectable staple for political rhetoric, but for many Americans he was no longer a model to be emulated. He did not make enough money. Honest hard work endured as something to be admired. But an instinct for opportunity came to be respected as well.

Americans have demonstrated a remarkable ability to reconcile the apparent contradiction between a belief in majority rule and the actuality of government by the few. This inconsistency has strained the ideology of popular sovereignty. This strain has been accommodated, however, in two ways. First, by conceiving of common interests between governors and the governed. Second, by the recognition (sometimes in words only) on the part of the governor that ultimate authority is conferred by the governed. In this way Americans have accepted an ambivalence between the exercise of government authority by the few and the social authority of the majority.

In antebellum America these tensions between a faith in majoritarianism and in a ruling class selected on the basis of merit were revealed in San Francisco. On one hand, it 
was believed that the social and political course of a community should be determined by the majority of its citizens. On the other, it was accepted that some men were more suited to positions of leadership and influence than others. This was demonstrated by their personal qualities (e.g. industry, moderate habits, talent) and usually measured by their wealth. ${ }^{49}$ These two sentiments were accommodated through an implicit acknowledgement that majoritarianism was best mediated in the practice of governance by meritocracy.

The tensions between merit and equality have been more or less successfully subsumed into the American political culture. Hofstadter has remarked on the "casual deference" which the self-made man often received from his neighbors. This allowed for the rapid development of political elites in frontier areas whom Hofstadter called "one-generation aristocrats."50 According to Hofstadter, the validation these elites received at the polls strengthened their faith in popular government. The "followers," in turn, could be confident in the leader acting as their advocate. Both the leaders and the electorate could see the other as advancing their common interests. A consensus was achieved.

49 For a cogent investigation into the belief in superior leaders see Garry Wills, Cincinnatus: George Washington and the Enlightenment (Garden City, New York: Doubleday and Company, 1984).

so Hofstadter, $45,47$. 
The "masses" and the "leadership," while they experienced conflict and appeared as distinct groups, were dependent on each other. The "leadership" required the validation of the "masses" for its programs and ideals and needed its approval, at the polls, at least, to maintain itself as the leading element of society. The "masses" desired that the "leadership" champion its interests and gained a sense of its own importance through its validation of the "leadership's" position and power.

These changes did not show themselves as perfectly thought-out attitudes. Part of the reason for this indistinctness was that two processes involved in the change, economics and politics, were each championed by a different political party. The Whigs and the Democrats brought different visions of the reordering of society in antebellum America. ${ }^{51}$ Except for the most devoted of the party faithful, individual Americans selected what they liked from each vision to suit their own circumstances.

The Democrats advanced profound political changes, successfully making political equality part of the American dogma, in the guise of a return to the principles of the Founders. The whigs embraced the new commercial order. A

51 See Ashworth, 7-84, for a discussion of the two parties. The Democrats have received the larger part of attention from scholars but Daniel Walker Howe, The Political Culture of the American Whigs (Chicago and London: The University of Chicago Press, 1979) concentrates on the Whig Party. 
meritocracy composed of men in a wide variety of occupations, enterprising and thriving in a commercial economy nurtured by government policies, was the ideal of the Whigs. 52

The Democrats enshrined the agrarian producer ethic. The Whigs cherished the idea of a ruling class of the natural elite. But the division between the two was not always clear-cut. Not all Democrats toiled behind their plow and avoided speculation and commercial endeavor. The Whigs enthusiastically adopted the Democrats' methods of mass mobilization in their own electioneering. Meritocracy and equality combined into a powerful dynamic that relegated the producer ethic and the natural aristocracy to positions of secondary importance. The striving of men to get ahead eclipsed the high-minded images of the hardy yeoman and the worthy governor. 53

Wealth and talent remained important assets to those who aspired to political leadership. But the presumption of privilege to positions of influence wilted under the tramping of aggressive mass electioneering. Jacksonian Democracy did not necessarily lift common men to positions of power. It did, however, have the effect of requiring those who sought such positions to make themselves appealing to the populace. Pessen puts it coarsely, maintaining that

52 Ashworth, 10-12, 68-73.

53 Ibid., 268-270; Watson, 211-212, 218-224. 
Jacksonian Democracy gave power not to the common man, "but to the shrewd, ambitious, wealthy, and able politicians who knew best how to flatter them." 54

One result of the rise in mass politics was to convince those who benefitted from it of the virtue of universal suffrage. The extension of the vote seemed an outstanding idea to those whom it elevated to office and thereby procured heretofore unattainable political spoils. Hofstadter found it developed in these new leaders a "faith in the wisdom and justice of popular decisions." 55 If the common man did not ascend to political office, his vote was valued by those who he helped elect. Equality became an enduring principle partly because of its utility to political aspirants and its empowerment of the many. The shift from a property-based political elite to a more widely-based electorate was a result of the economic changes of the market revolution and the progression of American political society. Equality had taken its place with liberty in the nation's ideological hierarchy. Equality was now the guardian of liberty. The representative democracy of the Founders had become the participatory democracy of Jackson.
54 Pessen, 347
55 Hofstadter, 47. 
THE MARKET CULTURE AND SOCIAI CONTROL

\begin{abstract}
Americans were struggling with tremendous changes in the antebellum era. ${ }^{56}$ Self-interest was more acceptable than in the past. Yet the market economy, which was largely responsible for this change, was paradoxically making individuals more interdependent. If a man was to participate in the market to get ahead, he could not remain isolated. The increasing attachments and connections created by the market economy and facilitated by improvements in communication and transportation, were conducive to conformity. In America the ordinary, middle class standard became the expected model of conduct. But the ordinary man was also striving to get ahead and looking for the "main chance" so he could be extraordinary.

Those who had held the positions of power in the eighteenth century -- the masters and gentlemen landowners - gave way to a new (though often overlapping) elite. Employers, capitalists, political bosses, and the profit motive took their places in the new order of things. Even when the old holder of power and the new were the same -the master become capitalist or employer, for instance -the relationship had changed. It was no longer a
\end{abstract}

56 For discussions of these changes see Ashworth, 2134 ; Watson, 17-41. 
paternalistic relationship, but an economic one. ${ }^{57}$

In his examination of the revivals of the Second Great Awakening in Rochester, New York, Paul E. Johnson recognizes the changed relations of the work place and in society generally. The manufacturers he studied became involved in a faith that preached individual free will. Christian men, of all classes, were men insofar as they took responsibility for their own behavior. Employers were no longer accountable for their charges' behavior. "A nascent industrial capitalism became attached to visions of a perfect moral order based on individual freedom and self-government, and old relations of dependence, servility, and mutuality were defined as sinful and left behind."58

The view that virtue resided in control over one's labor, rather than the ownership of the means of production, also contributed to the change in relation between employer and employee. The relationship became less and less familial and more of a purely economic association. The common man and the "masters" met only in the political or economic marketplace. ${ }^{59}$

As the role of traditional authorities was changing, mass politics took hold. Technological improvements in

57 See Paul E. Johnson, A Shopkeeper's Millennium: Society and Revivals in Rochester, New York, 1815-1837 (New York: Hill and Wang, 1978).
58 Ibid., 111, 141 .
59 Ibid., $38,42-43,47$. 
printing and low postal rates for newspapers stimulated the spread of party dogma. Money and prestige were still powerful, but (nearly) every man had the power of his vote. The traditional authorities gave up or lost their paternal power. And while the common man lost some of the security that had been inherent in the old master-worker relationship, he gained some of the power that the master had formerly had over him.

This meant new means of social control would have to be employed. Production through wage labor required a more regularized and regimented society, one in which individuals (who had free will after all) should conform to middle class expectations by showing up for work sober and on time and carry themselves with middle class comportment. With large numbers of people who seemed unwilling to do these things, institutions were developed and strengthened (e.g. asylums, public schools, and reformatories of all kinds) that would enforce these standards. 60

The revivals of the $1820 \mathrm{~s}$ and $1830 \mathrm{~s}$ provided another model for social control. Johnson argues that these "revivals were a means of building order and a sense of common purpose among sovereign, footloose, and money-hungry

60 Sellers, 363-365; On the new institutions of social control see Christopher Lasch, "The Origins of the Asylum," in The World of Nations (New York: Alfred A. Knopf, 1973). 
individualists."61 Importantly, they had characteristics of other forms of social control. The revivals, Johnson notes, relied on "individual conversion and public example, and increasingly ... mass politics and outright coercion" to improve society and prepare it for the second coming. ${ }^{62}$ The vigilantes in San Francisco used similar methods to impose social order twice during the $1850 \mathrm{~s}$.

Ronald G. Walters, in his study of antebellum reform movements identifies their key characteristics: "millennialism and immediatism."63 Americans seemed to have an unshakable faith in continued and dramatic improvement. A better world was always possible. Progress, after all, necessarily sprouted from democracy. But hope for the future was not enough to sustain Americans, they wanted results. Foreign visitors were impressed (not always favorably) with the restless activity of Americans. Americans felt determination was a greater virtue than patience.

Americans were not, however, particularly willing to discard old values arbitrarily. There was a paradox between the sweeping changes of the antebellum period and the fierce loyalty to and reverence for the ideals of the founding

61 Johnson, 9 .

62 Ibid., 6.

63 Ronald G. Walters, American Reformers, 1815-1860

(New York: Hill and Wang, 1978), 18. 
period. There was a sense that the founding had been an achievement of the highest (perfect) order. Accordingly, when Americans experienced something that they felt was not right it created intense anxiety. It was a disruption of their ideal society.

Walters finds this anxiety to be a common theme among a collection of more or less unrelated movements. He compares the reform movements of his study with antimasonry, nativism, mobs, and the pro-slavery crusade. He finds that all were reacting to a sense that "old values were being lost and something or someone was to blame. Whatever was at fault had to be eliminated or controlled if America was to fulfill its destiny."64 The vigilantes in San Francisco did not feel that old values had been lost, but that familiar values had not taken root in their city. They tried to eliminate what they perceived to be barriers to the establishment of these values.

In antebellum America, urban riots were often a response to changes or conditions perceived as unjust. Though violent and deadly these riots usually had some bounds of conduct. They were almost always directed at the perceived source of injustice, and efforts were even made to prevent injury to innocent parties. Fires that were intended to destroy a malefactor's property might have to be put out to protect adjacent property, for example. In other

64 Ibid., 10. 
cases rioters chastised their fellows for stealing rather than destroying property. ${ }^{65}$

The sense of limits to behavior during riots stemmed from the place in culture that rioting assumed. The riot was not a pointless rampage. It was a form of mass social control. But neither was it a model of probity. David Grimsted in his study of rioting in the Jacksonian era found that the riots did not "readily fall into categories of either 'irrational' or 'socially purposeful' behavior."66

Rioters and others who used violence to enforce their conception of justice were not rejecting society but rather trying to modify it. They were usually sure of what they were against, bankers, for example, so the target of their anger was focused. But their hoped for outcome, such as financial security (which seemed threatened by bankers), tended to be complex and elusive. Thus the consequences of such violence were apt to be inconclusive. Similarly, the vigilantes in San Francisco saw public violence as a means of modifying their society. The results of their violent acts were also inconclusive.

Achievement of an outcome was a strong reason for groups to organize, but another factor was also important. It was the sense of belonging felt by those who joined

65 See David Grimsted, "Rioting in Its Jacksonian Setting," American Historical Review 77 (1972): 61-397.

66 Ibid., 379. 
together for a purpose. This transcended whether the goal was reached or not. The ongoing manifestations of the use of violence as social control -- the fire companies, urban gangs, and vigilance committees -- survived not only because of a goal, but through the feeling of fraternity among their members. In the absence of traditional sources of support such as the family and church, these organizations took on a prominent role in reassuring the individual of his place in society. Mary P. Ryan found that associations of the $1830 \mathrm{~s}$ helped young men form a "new kind of social bond, one based on common interest, age, and status and nourishing, warm, democratic, mutually supportive emotional ties."67

On the frontier, where conventional institutions were undeveloped and the population was transient, voluntary associations were not just surrogate social supports, but a method of social control. Don Harrison Doyle argues that voluntary associations, such as political parties and vigilance committees, "were designed to integrate and order a transient community ... they enforced the values of social discipline in their members."68

Antebellum man was committed to his own improvement and

67 Mary P. Ryan, Cradle of the Middle Class: The Family in Oneida County, New York, 1790-1865 (Cambridge and New York: Cambridge University Press, 1981), 127-132, quote is from 129 .

68 Don Harrison Doyle, The Social Order of a Frontier Community: Jacksonville, Illinois, 1825-1870 (Urbana, Chicago, and London: University of Illinois Press, 1978), 11 , quote is from 16. 
upward mobility: his self-interest. Yet he longed for a feeling of community. He was steeped in a political culture that valued equality and endorsed majoritarian decision making. Americans expected constant improvement in society and employed various means to bring it about: mass politics, the pressure of self-appointed elites who expressed themselves through reform movements, and violence. All these social undertakings were informed by an American impulse for popular action. California, with its fledgling civic institutions, provided an extraordinary environment in which men tested the limits of social action. 
CHAPTER III

GOLD RUSH CALIFORNIA: CHAOS AND COMMUNITY

When fabulous finds of gold were confirmed (and later exaggerated) in California it presented a magnificent opportunity to Americans for rapid and dramatic advancement. It appeared to be a place where men had a relatively equal opportunity to apply labor to a task and become rich. It was not the producer ethic that sent men to the gold fields, but the prospect of nearly instantaneous success. California's rich placers were seductive. J. S. Holliday writes about the men for whom "the frugality of generations gave way to a contagion of optimism and ambition, responsible family men found their jobs and prospects unrewarding when set against all that California could provide."1 The frustrations attendant to some Americans" obsession to get ahead could be realized in short order. California seemed to embody the authenticity of upward mobility: Men really could get rich quickly. The economic parity that California promised seemed to fulfill the antebellum era's pledge of political and social equality.

1 J. S. Holliday, The World Rushed In: The California Gold Rush Experience (New York: Simon and Schuster, 1981), Holliday, 50 . 
California also tested the political and cultural developments of the antebellum era. In the older states traditions and institutions cushioned the impact of equality and mass politics. The mines and towns of California experienced these phenomena without the benefit of an existing order. And few of the men pouring into California were concerned with building order. They wanted gold and they wanted it quickly. Hofstadter's Jacksonian man and Pessen's greedy materialist came in force to California. ${ }^{2}$

It was not just Americans who came to California. Men came from Europe, South America, Mexico, Australia, and China. While Americans established their cultural hegemony, there was still a commonality among the gold seekers. To paraphrase Dorothy Johansen's "Working Hypothesis for the Study of Migrations": Migrants to a particular place are similar because they are drawn to that place by similar motivations. It is the "pull" of the place to which men irnigrate rather than the similarity of the place from which they emigrate that gives distinctive character to new communities. ${ }^{3}$

The type of man who came to California had a desire to move up in the world, and to do it quickly. He was immersed in the American dualism of fierce individualism and

2 Supra, Chapter 2, 47.

3 Dorothy Johansen, "A Working Hypothesis for the Study of Migrations," Pacific Historical Review 36, no.1 (February 1967): 11-12. 
dedication to majoritarian politics. He enjoyed both the feeling of unassisted achievement and that of joining his fellows in a common effort. He accepted violence, coercion, and mass politics as acceptable means of community enforcement of social control. He was clearly more adventuresome than his neighbor who stayed home. Although gold seekers brought an American heritage with them, it was the unique situation in California that would make its society distinct from other parts of the country. The opportunity embodied in California seemed to affirm that men could be equipotent -- economically, socially, and politically. It sustained Americans' propensity to seek a natural order of things.

California nas, of course, unprepared for the gold rush. The Mexican-American war had only recently ended. Traditional Spanish and Mexican forms of government mixed with the American military government and often resulted in ad hoc combinations. The Mexican office of alcalde might be filled by election or appointed by the military governor or both, resulting in confusion and disagreement. These same alcaldes could be found presiding over American-style jury trials, which remained unacknowledged by any existing legal code. This uncertain situation was aggravated by a lack of action from Congress, which was paralyzed by the growing sectional crisis, in providing for a government for 
California. ${ }^{4}$

The Treaty of Guadalupe Hidalgo left the area in governmental limbo. The Mexican forms and officers could not rule and the military government (theoretically, at least) was prohibited from operating in peacetime. Californians of American heritage were demanding their own civil government. In 1847 the California Star editorialized about the lack of written law. The editor remarked that "some contend that there are really no laws in force here, but the divine law, and the law of nature."5 It was a portent of things to come.

GOLD RUSH CALIFORNIA: THE SETTING

The first rumblings of gold finds in California reached the United States in August of 1848. When President James Polk confirmed the discovery of extensive gold finds in California in his annual message on December 5, the excitement over gold took on a frantic character. Those with means and inclination boarded ships bound for san Francisco. Others planned for the long overland trek the following spring. Joint stock companies sprang up all over

4 Mary Floyd Williams, History of the San Francisco Committee of Vigilance of 1851 (Berkeley, California: University of California Press, 1921, reprint; New York: De Capo Press, 1969), 23-39, 132-133.

5 Quoted in ibid., 38. 
the world, offering those of more modest means an opportunity to make the trip and those of less adventurous spirit a chance to profit while remaining behind. Tens of thousands dashed, as best they could, for California. The deluge of people that went to California was remarkable. Rodman Paul estimates that the population increased from 14,000 in 1848 to nearly 100,000 by the end of 1849. When California took its own census in the latter part of 1852 it found some 223,000 residents. Nearly 700 vessels had entered San Francisco's harbor by the end of 1849. Many crewmen deserted. This phenomenal growth did not give time for institutions to grow gradually. ${ }^{6}$

Whether an Argonaut chose the debilitating sea voyage or the severe overland trek, the journey itself became a part of his identity and in some way tied him to his fellow gold seekers. It also ensured, in the words of Paul, that he would arrive "exhausted in mind and depleted in pocketbook."7 As such it was part of the leveling experience of California.

Important to the aura of equality in California was the function of land. Except along the wharves it was of marginal value. In the mining regions it was impossible to

6 Rodman Paul, California Gold: The Beginning of Mining in the Far West (Lincoln, Nebraska: University of Nebraska Press, 1947), 25; Holliday, 297; Carey McWilliams, California: The Great Exception (New York: Current Books, 1949), 49 .

7 Paul, 34 . 
secure title to a piece of land. The land was ostensibly owned by the United States government which had not promulgated any laws for its transfer to citizens. Mining claims were administered locally under various systems of miners' law. These codes universally required that a man work his claim and limited what he could claim to no more than he could work. Thus property did not find a tangible manifestation in land, but rather was defined in a man's ability to labor. This gave substance to the sense of equality in the mines. 8

Placer mining required little beyond the physical presence and effort of the miner. The tools and methods were simple. Only a small plot or length of stream bank was necessary for a claim. Other occupations required skills, capital, land, or some combination. In California, determination, a pan, and a shovel, along with a bit of luck, could make a man rich in a season. Alexander Saxton maintained that in the California foothills, "the producer ethic found a basis of genuinely equal opportunity." 9

But the virtue of the producer ethic was stained by the crass avarice of the success ethic. Men came to California

8 For a discussion of land laws in the mining regions see Charles Howard Shinn, Mining Camps: A Study in American Frontier Government (1885; reprint, New York: Alfred A. Knopf, 1948), 221-246.

9 Alexander Saxton, The Indispensable Enemy (Berkeley, Los Angeles, and London: University of California Press, 1971), 52 . 
to get rich. Holliday characterizes the gold seekers as lacking in a sense of civic responsibility:

These people came to take, not to build... they found themselves surrounded by crowds of hurrying men concerned only with how to make the greatest amount of money in the shortest time. With that common motive, they also shared an indifference toward California and its future.... No one wanted to be tied down and burdened by social responsibility. ${ }^{10}$

Their civic identity was undeveloped. They were a sea of faceless men, lacking a common past, and moving about incessantly. ${ }^{11}$ The population was overwhelmingly young and male. They lived in tents and other temporary dwellings, not homes. The conventional enforcers of the moral order -family, church, and employer -- were by and large absent.

The miring areas characterized the primitive community organization in California. Mining camps grew and died at a bewildering rate; they often had an ephemeral character. It was here that the men that came to California congregated and faced nature. Individually, or in small groups, miners passionately pursued their self-interest.

The California experience was harsh. The miners strived to fashion wealth directly from nature. They were acquisitive, mobile risk-takers. This changing, uncertain society of equals, each endeavoring to subdue nature for his own interest, lent a sense of insecurity to California.

10 Holliday, 297.
11 Williams, $136-137$.


This insecurity felt dangerously close to anarchy or a state of nature.

California was on the one hand frantic and unstable. But it also had the uniformity of individuals joined together by common pursuit of their individual interest: gold. The mutually reinforcing dispositions of individualism and majoritarianism in Americans came into play in the mining regions.

Mary Floyd Williams defined the "crucial moment" for miners as that when an individual prospector's strike became public knowledge. The situation would bring together "excited men, in a remote mountain gorge, with gold uncovered at their feet and loaded weapons in their hands."12 Williams drew a scene of miners laying aside their guns and amicably dividing the placer in a fair and equitable manner. She attributed this solution to "swift agreement by the will of the majority on matters of common interest, and cheerful loyalty to such decisions."13

The miners were certainly committed majoritarians. But williams ignored an essential aspect of her "crucial moment" in the miners' existence: the coercive power of the majority. There was little a lone prospector could do when faced with a group of interlopers. And should he combine with them he would gain security and the individual power
12 Ibid., 65.
13 Ibid. 
inherent in association. Popular sovereignty was not the benign arbiter of social good as williams characterized it. The threat of violence and disorder were compelling motives for a maintenance of consensus.

In important ways the social combinations of the miners resembled a Lockean contract. They were men in a state of nature (or very close to it) who gave up a portion of their liberty in exchange for security of their property, in this case the security of one's claim and gold.

As they expanded and extended political power, pushing it closer to a state of nature, Americans remained concerned with the preservation of social order and the protection of the individual. Faced with a virgin continent, Americans had always sought to rise above a state of nature, to a society where rights could be secured. Even under the influence of the grasping success ethic they recognized the feebleness of the individual. The sanctity of property and, later, the dignity of labor, had served as bulwarks to protect individual liberty. Both derived their power from the will of the community. If men were to use wealth to ensure their liberty, it, too, would require the community for its preservation. The mass of citizens had to collaborate to protect their individual liberty from government, monopolies, or depraved minorities. ${ }^{14}$

14 For a discussion in this vein of Californians' opposition to existing government during the early gold rush and their attempts to create their own government see David 
MINERS AND MERCHANTS

The growth in the population of California, and San Francisco in particular, was impressive but not unprecedented in America. Chicago, for instance, grew at a remarkable rate during the antebellum period. Yet no vigilantes seized power there. The hinterlands of Illinois, however, were not filled with gold. The presence of gold was fundamental to the California experience. It was gold, after all, which defined the mass of immigrants that came to San Francisco. There were two groups of fortune seekers: those who planned to make their "pile" in the mines and those who planned to profit from the abundance of miners. These two groups shared some characteristics; most notably, virtually all were men, relatively young, and had recently immigrated to California. Most of them also shared a commitment to antebellum American values of democracy. They believed in an equality that allowed all to jockey for status in an American society in which wealth was the most widely accepted measure of merit.

The different methods these two groups, miners and merchants, employed to seek wealth is crucial to understanding the San Francisco vigilance committees. The

A. Johnson, Founding the Far West: California, Oregon, and Nevada, $1840-1890$ (Berkeley, Los Angeles, and Oxford: University of California Press, 1992), 15-40. 
miners came from a society that was anchored in the producer ethic, but was increasingly animated by the success ethic. They hoped to circumvent the long-term commitment that the producer ethic assumed. Few, if any, dreamed of setting down roots in California in the same way that the farmers of Oregon's willamette Valley or Illinois had done. The miners thought that a season, perhaps two, of hard work would make them wealthy men.

This said, a proximate (not immediate) longing for middle-class respectability did drive the miners. They accepted bourgeois standards of success. The rich placers held the promise of fortune without the conventional mode of attaining it via delayed gratification. The credibility of wealth that California's gold promised to bring could be attained without the burdensome middle-class routine of thrift, sobriety, self-control, and the prospect of endless work. The miners were in some ways reconciled to the middle-class order and yet dedicated to avoiding the life that was normally associated with such standards.

If the miners were adventurers with dreams of nearly painless transformation to the higher reaches of society, the merchants were, initially at least, similar. Peter Decker has chronicled the uncertainties of the California market and the high turnover in San Francisco's merchant class. Like the niners San Francisco's merchants were an impermanent population with an uncertain future. The 
consignment of a cargo from the east -- any cargo, it was thought -- could be sold at high prices to the miners producing correspondingly high profits. A particularly fortuitous selection of merchandise would translate into even greater profits. One shrewd speculation might produce a fortune. Of course the reverse was true as well. ${ }^{15}$ As Decker (and others) have pointed out, gold rush merchants desired a less volatile marketplace. ${ }^{16}$

Equality was magnified by the country's fluid social structure. A week of good panning or a fortuitous load of merchandise could catapult a miner or merchant into the first ranks of society. But as the initial excitement of the gold rush wore off these sort of opportunities began to be seen as exceptional.

As time went on, stacks of unsold merchandise covered San Francisco's streets and wharves. Merchants began to accept that more conventional commerce, and not rapid accumulation, would be typical of san Francisco's business, as it was in the East. As the exhilaration of the city's merchants subsided, they settled in for the long haul. They

15 Peter R. Decker, Fortunes and Failures: WhiteCollar Mobility in Nineteenth-Century San Francisco (Cambridge, Massachusetts and London: Harvard University Press, 1978), 32-59.

16 Decker, 37-52; Robert M. Senkewicz, Vigilantes in Gold Rush San Francisco (Stanford, California: Stanford University Press, 1985), 36-43; Roger W. Lotchin, San Francisco, 1846-1856, From Hamlet to City (Lincoln, Nebraska and London: University of Nebraska Press, 1974), 49-64. 
began to expect middle class behavior not only of themselves, but of the others who inhabited "their" city. The drunkenness, gambling, and general rowdiness that had been typical of California life were recognized as an impediment to the establishment of more conventional lifestyles and forms of business.

Before San Francisco could become a solid, middle class city it had to mature, build institutions, and establish cultural restraints. But the "settlers" in the city were still far outnumbered by the transient portion of the population. Institutions, of both society and government, needed to be developed to transform San Francisco into a respectable city. The influence of society and culture were needed to remove the roughest edges from the city. As the city's major newspaper, the Alta California observed in the summer of 1851, "the lyceum and the lecture room were on the other side of the continent."17

There were few institutions of government in California when the gold rush deluged the region in 1849. But what institutions that existed (the military government and Mexican forms of government) immediately clashed with American precepts about government. This aggravated traditional American suspicions of government. The bulk of California's population was relatively apathetic toward the development of government (except for that which would

\footnotetext{
17 Alta California (San Francisco), 18 June 1851.
} 
secure their mining rights long enough to extract wealth from the earth). The portion of the population that was interested in government, the merchant class, was also the busiest. But, imbued with the American spirit, they expected the government to answer when they called. This resulted in a crisis-oriented and haphazard civic life.

As civil governments were elected and put into place, many San Francisco merchants saw only the institutionalization of the defects that had heretofore existed in California. They complained about the incompetence and feebleness of the local and state authorities with vigor. By late 1850 the Alta, having decried the lack of government during the interregnum, charged that the state and city governments were worse than no law at all. Their stupidity and incompetence was costly, the laws they passed were contemptible; they encouraged lawlessness. The Alta estimated that San Francisco pould be between "one thousand per cent" and "infinitely" better off without the city charter and the laws passed by the councils. ${ }^{18}$ San Francisco had not settled down as quickly as it had grown up, and this bothered many merchants. The general disregard for social conventions and behavior took on magnified importance in light of the devastating fires the city experienced and what seemed to be a rising, or at least unacceptable, level of crime. Fires

18 Ibid., 5 January, 21 February 1851. 
had been a problem even before the gold rush, but beginning with the first great fire in December 1849 the city suffered from a series of what Roger Lotchin has characterized as "holocaust[s]." Three terrible fires in 1850 were followed by two more in 1851. ${ }^{19}$ Much smaller and less destructive fires served as a regular reminder of the possibility of fire raging out of control. The lawmakers of the city and state seemed incapable of creating a system that would alleviate these problems.

Much of the dissatisfaction with government revolved around this perceived (and actual) increase in crime and the authorities' apparent inability or unwillingness to combat it. The popular justice of the mines, though without legal sanction, was influential because of the perception that it was capable of bringing about justice.

Anericans have been intuitively reconciled with the notion that an abstract sense of justice, and not the imperfections of concrete laws, should guide society. As the makers of law, the people can legitimately claim to be the arbiters of social order. There has rarely been sympathy for those who engage in criminal activity unless that activity is directed against unpopular institutions or is the result of the perpetrator's desperation. Such apologies for criminal behavior were absent in san Francisco. The city lacked strong institutions. The

19 Lotchin, 174-175. 
richress of the mining regions seemed to preclude the necessity for crime due to unfortunate circumstances. While boisterousness, fights, and drunkenness found acceptance with a large part of the population, larceny, robbery, and murder were considered particularly reprehensible behaviors in the (apparent) land of plenty.

SOCIAL CONTROL IN THE MINES: LYNCHING

In the mines transgressors of the social order were often dealt with summarily, but usually through some mechanism which involved the immediate community to some extent. The "law of the mines" required some sort of hearing, though it often was exceedingly informal and did not uniformly provide the accused with representation. Judgments were made by the entire body of gathered miners or by a selected group. In either case they could be fairly classified as demonstrations of popular governance. Representative of this was the report of a man sentenced for burglary and theft: "He was executed with the unanimous approval of the people of stockton."20 The accused were not provided with conventional legal protections, but rather relied on a sense of fairness or justice from the assemblage or its officers. In this way it was a stark illustration of the power of a community governed by popular sovereignty.

20 Alta, 9 August 1849. 
The individual and collective sense of justice was enforced through the power of numbers. ${ }^{21}$

David Johnson has documented more than 200 cases of lynching in California between 1849 and $1853 .{ }^{22}$ Most of these occurred in the mines or along the supply corridors that served the mining regions. Punishment, due to a lack of jails, was physical. Whipping, beating, banishment (sometimes accompanied by mutilation to identify the transgressor), and hanging were employed. Some suspects were remanded to the authorities. Others were acquitted by the miners' courts. ${ }^{23}$

The Alta reported a typical example of the methods of justice in the mines. After it was learned that four men had robbed the proprietors of a drinking and gambling establishment at Dry Diggings of $\$ 600$,

a large party of armed citizens proceeded to the house of the four robbers and arrested

21 See Paul, 202-206; Williams, 148-152; Josiah Royce, California, From the Conquest in 1846 to the second Vigilance Committee in San Francisco (reprint, New York: Alfred A. Knopf, 1948), 256-271; Shinn, 119-120, 216-219; Bayard Taylor, Eldorado, or, Adventures in the Path of Empire: Comprising a Voyage to California, via Panamai Life in San Francisco and Monterey; Pictures of the Gold Region (New York: G. P. Putnam and Son, 1850,1862; reprint, New York: Alfred A. Knopf, 1949), 76-78.

22 David A. Johnson, "Vigilance and the Law: The Moral Authority of Popular Justice in the Far West, "American Quarterly 33 (winter 1981): 564. Richard Maxwell Brown has considered vigilantism and violence on a national scale. see his strain of Violence: Historical studies in Violence and Vigilantism (New York: Oxford University Press, 1975).

23 See Johnson, "Vigilance and the Law," 564, 570. 
them. The next day the citizens assembled and selected three judges who were to try the four men. Twelve jurymen were drawn by ballot, and the trial at once took place. The jury returned a verdict of guilty of robbery, and the four men were sentenced to receive thirty-nine lashes each and to be banished forever from the mines. ${ }^{24}$

The sentence was carried out the next day. For the Alta it was "most gratifying to observe the determined spirit of justice which actuate the people thus situated, and the creditable zeal with which this outrage has been punished."25 But there were limits to the Alta's enthusiasm for popular forms of punishment. It was "inexpressibly shocked" when a committee of the state legislature considered authorizing whipping as a punishment for grand and petit larceny. ${ }^{26}$ In another instance it hoped the people of Stockton had not resorted to "the barbarous forms of Judge Lynch; such as shaving the head, lopping the ears, and other disgraceful mutilations of the person." Such punishments were a "mockery of law and [an] outrage [to] ... humanity." 27

In the first years of the gold rush the Alta, while nominally deprecating lynch law, continually praised its effectiveness: "Criminals stand but a poor chance in the

\footnotetext{
24 Alta, 8 February 1849.

25 Ibid.

26 Ibid., 10 April 1850.

27 Ibid., 9 August 1849 .
} 
mines."28 Though insisting that a revision of the laws would remedy the situation, the paper intimated that established areas, such as San Francisco, would be forced to resort to the methods of the mines to protect themselves, due to the inefficacy of the laws.

There is a set of devilish thieves and villains about this city, and we fear their depredations can only be checked by the prompt sentence of Judge Lynch. Police and courts seem to be but little dreaded if at all, and afford little protection. We hope the next robbery committed will cost the villain an aerial dance. ${ }^{29}$

The Alta's flirtation with lynch law illustrated the ambiguity of its commitment to middle class values of law and order and its congeniality to the methods of social control employed in the mines.

\section{MIDDLE CLASS VALUES IN SAN FRANCISCO}

This desire for the institutionalization of middle class values is apparent throughout the columns of the Alta in 1850 and 1851. The editor concerned himself with issues that were likely far from the minds of most fortune hunters in California: the need for public schools and orphanages; the necessity of segregating lunatics, women, and minors from the general jail population; the deleterious effects of
28 Ibid., 3 June 1850.
29 Ibid., 2 October 1850. 
gambling, both on the gamblers themselves and the city at large; the virtue of voting for the "best" man as opposed to party-line voting; and the general call for better city services (fire, police, roads, etc.), sometimes even accompanied by suggestions of raising revenue to pay for them. The editor was gratified at the increased observance of the sabbath and the proliferation in churches. These issues were typical concerns expressed by those wishing to impose middle-class expectations on the community, and not, one would expect, foremost in the minds of typical California miners or temporary residents of san Francisco. 30

Voluntary organizations were also manifestations of the desire for a conventional social order. ${ }^{31}$ The California Guard (a militia unit) and the fire companies provided camaraderie and served useful functions within the community

30 Ibid., On the need for schools and hospitals see 12 July 1850; on lunatic asylums see 3 April, 13 May 1851; on the Ladies Orphanage Asylum see 21 June 1851; on the need to segregate women and minors see 11 November 1850, 1 April, 26 May, 23 July 1851; on party-line voting see 20 June, 5 October 1850, 22 July 1851; on gambling see 13 October, 28 November, 19 December 1850, 26 January, 1 February, 4 April, 6 June 1851; regarding the observance of the sabbath and churches see 25 May, I June, 18, 20 July 1851.

31 On the role of voluntary associations see Don Harrison Doyle, The Social Order of a Frontier Community: Jacksonville, Illinois, 1825-1870 (Urbana, Chicago, and London: University of Illinois Press, 1978), especialiy 1116 and 156-157, and Mary P. Ryan, Cradle of the Middle Class: The Family in Oneida County, New York, 1790-1865 (Cambridge, London, and New York: Cambridge University Press, 1981), 127-132. 
but were not necessarily exclusively middle class. They were examples of harmonizing institutions that cut across class lines. Others seemed more typically middle class: the Chamber of Commerce, the Merchants Exchange, the Society of California Pioneers, the Antheneum Club, the Eureka society, the Odd Fellows, the Masons, the San Francisco Antiquarian Society and San Francisco Academy of Arts and Sciences, and the Sons of Temperance.

The Alta California was decidedly middle class in its tone and spoke for the emerging commercial class. Two complaints in particular demonstrated the paper's prejudices. Both instances illustrate a rejection of the audacious public behavior that suffused California. The editor's complaints foreshadowed the underlying tension between middle class values of order and the prevailing sentiment in California for a continuation of the freewheeling status quo.

The crudeness San Franciscans exhibited at political gatherings demonstrated to the Alta a need for restraints on behavior. The editor fumed about those who "disturb the harmony of meetings for the creation of what they conceive to be 'fun'."32 When a procession protesting what they perceived to be high taxes marched to a town square, a number of the crowd hissed and groaned at the common Council. The Alta saw this "deliberate insult" to duly 
elected officials as the "action of a mob."33 For many San Franciscans politics was useful only insofar as it had entertainment value. Even settled parts of the United States had their boisterous political elements. In san Francisco, where the average citizen was young and male, rowdiness could be expected to be the norm.

In another case, the editor of the Alta denounced a portion of an anti-tax crowd that included men who were "possessed of the most radical and levelling ideas [and] were in favor of no taxation and no government, upon the general principle that all men are born free and equal and ought to be able to govern themselves."34 Clearly, the editor felt a need to establish controls on the ungoverned portion of society. And, just as clearly, he believed that there was a significant element in California that needed to be restrained.

Even the merchant class had, at best, an uneasy appreciation for the city government and its functions. They were conditioned to democracy yet wary of the majority which seemed disposed to excess and abandoned behavior. In the best American tradition the commercial class adapted to the conditions of San Francisco. They found a way to incorporate their values of order into the unconfined male society of California.
33 Ibid., 5 June 1850.
34 Ibid., 11 June 1850. 


\section{SOCIAL CONTROL IN SAN FRANCISCO}

One of the veneers of civilization in San Francisco was the use of more modern methods of social control: municipal police, courts, and incarceration as a method of punishment. In the spring of 1850 a hopeful Alta reported on the city's "well-arranged and indefatigable police" and "our Courts of Justice in which the weak are protected from the attacks of the strong."35 But the city's residents felt ambivalent toward government generally and these institutions had not yet become firmly established. The acceptance of a professional justice system was hampered by the presence of another model: the methods of the mines. The alternative offered by lynch law as practiced in the mines, was especially attractive in socially undeveloped California. The Alta recognized that society in California was not mature: "a social compact is wanting, and a social system imperatively demanded." 36

Law enforcement in the mines was associated with lynching. Not until the formation of the vigilance committee was anyone hanged in San Francisco. However, several incidents in which lynching was advocated indicate that the practice was not unfamiliar to the city. Late in 1850, while complaining of crime, the Alta suggested that if

35 Ibid., 17 May, 5 March 1850.

36 Ibid., 22 December 1849. 
the authorities did not act more vigorously, that an "outraged community" would turn itself into a "Lynch tribunal." 37

During the first week of January 1851, a pickpocket was nearly hanged by an angry crowd. A police officer succeeded in taking the suspect to jail. ${ }^{38}$ A month later a pieman was shot by a man reputed to be a thief. It was only with "difficulty the people were restrained from Lynching the scoundrel."39 The most striking incident, prior to the acts of the vigilance committee, occurred two weeks later. Two men were nearly hanged even after a citizen's court had acquitted them.

The Jansen incident, as it became known, is generally seen as a precursor to the committee. In the wake of the excitement the Alta printed a warning to "rogues" that the "community seem to be determined to inflict summary punishment upon any man caught in criminal act." 40 when the editor of the San Francisco Herald, William Walker, ${ }^{41}$ was jailed for contempt of court by Judge Parsons, a number of citizens advocated extricating walker by force from the

37 Ibid., 31 December 1850.

38 Ibid., 5 January 1851.

39 Ibid., 7 February 1851.

40 Ibid., 26 February 1851.

41 This is the same William Walker who later gained notoriety for his filibustering expeditions in Nicaragua. 
jail. The crowd settled for "strong condemnatory resolutions," and calls for Parsons's resignation or impeachment. ${ }^{2}$ A strong escort of police prevented William Slater, accused of the murder of Captain Jarvis, from being taken by a group of horsemen bent on inflicting their own punishment. 43 In May, the editor of the Alta angrily denounced those who allowed convicts from sydney to arrive in San Francisco aboard ship. The "authors and abettors of this outrage," thundered the Alta, "deserve to be lynched without mercy for their villainy."44 Though no lynchings had yet taken place in San Francisco, it figured prominently as a possible solution to the citizens' frustrations. San Francisco could not escape the context of a California defined by the mines and the miners. Extralegal modes of social control were acceptable in California so long as they had the community's endorsement. The endorsement of the community was also necessary for duly authorized forms of social control. In more established areas alternative models of social control (such as vigilantism) were absent or poorly defined. The urban riots of the East Coast certainly were efforts to modify behavior, but lacked a coherent apparatus to methodically pursue a

\footnotetext{
42 Alta, 17 March 1851.

43 Ibid., 1 April 1851.

44 Ibid., 10 May 1851.
} 
given set of objectives. ${ }^{45}$ San Franciscans had a readily available model: vigilantism. The merchants, with a disposition toward organization, were well equipped to adapt the spontaneous vigilantism of the mines along well-ordered lines of conventional middle class organizations.

The resort to vigilantism by San Franciscans was a response to changing conditions in California. The state was becoming more settled and more receptive to typical middle class attitudes and behavior. The Alta could "see the germs of a far more healthy state of feeling springing into life among us. A large proportion of our population is of right description, hardy, enterprising, industrious, who love good laws and good government, and who will make the one and support the other."46 "The fact is," asserted the Alta, "we are fast settling down into the permanent customs and habits of the Atlantic cities."47

The merchant class of San Francisco was becoming more confident and assertive. This assertiveness manifested itself in one way through the vigilance committee of 1851 . In California the notions of order and popular, extralegal action were reconcilable. Vigilantism, although it was illegal, so long as it exhibited the virtues of dignity, discipline, and fairness, could be the very embodiment of
45 Supra, Chapter I, 42-43.
46 Alta, 30 December 1850 .
47 Ibid., 20 March 1851. 
the American ideal of self-government. By June of 1851 the city's merchants, or many of them, had convinced themselves that it was their duty to take matters of justice into their own hands.

Expectedly, the first hints of this drift to vigilantism came from the mines. In the last part of 1850 the Alta was becoming alarmed by robberies and murders in the mining regions that, it claimed, were going unpunished. ${ }^{48}$ It was important that the effects of new state laws were partly to blame for this development:

Among the reasons that conspire to make this sad change since last year, when such crimes were few and generally followed with speedy punishment, may undoubtedly be reckoned the inefficiency of the laws, as now existing in the courts, and codes established by the legislature. ${ }^{49}$

Popular action, through lynchings, had seemed to impose order. Government action seemed poorly adepted to the special circumstances of California.

The migratory character of the mines made them unsuitable for conventional laws. The transitory nature of the mining population made it necessary for suspects to be tried promptly, before witnesses had left the area. The Alta demanded that the legislature "adapt the law to the

48 For examples of crime in California see Alta 19, 31 July, 9 August, 16 September, 2, 13, 26 October, 12, 28 December 1850 .

49 Ibid., 16 september 1850 . 
necessities of the country." 50

It did not take long for this affliction of unpunished crime to find its way to san Francisco. By the end of the year, according to the Alta, there had been a "horrible increase in crime." Robberies and murders were committed "without any apparent dread of detection and punishment." The city administration was warned to act lest "an outraged community take into their own hands the administration of law."51 The government was being put on notice that there would be consequences for its inaction.

The source of this explosion of criminal behavior, according to the Alta, was two-fold. Part of it stemmed from the unrestrained society in California; a "general laxity of moral feeling," as the Alta termed it. The other came from the presence of supposedly large numbers of convicts who had come from Britain's penal colonies. 52 These convicts were blamed as "the great leprosy that is rendering the whole surface of our present society hateful

50 Ibid.

51 Ibid., 31 December 1850.

52 Senkewicz reports figures showing that less than twenty percent of the immigrants from Australia were exconvicts, 79. See also Jay Monaghan, Australians and the Gold Rush: California and Down Under, 1849-1854 (Berkeley and Los Angeles: University of California Press, 1966). Even the Alta wondered whether sydney immigrants had been blamed for too large a share of the crime committed in san Francisco; see 26 October 1850. 
and disgusting." 53

For these reasons, according to the Alta, California lacked the restraints of law and public opinion. "Here the cry of gold and a fancied impunity in evil brought" those of questionable character. 54 Many who had "maintained tolerable characters" in more established parts of the country, when freed from the restraints of society in California, "at once threw themselves into the dissolute and abandoned courses, which, not principle but restraint had previously kept them from."55 Such men lacking in selfdiscipline clearly would have to have restraint imposed upon them by the power of the community. This group included not only criminals, but the large numbers of men who did not behave themselves.

During the early days of the gold rush the moderation of behavior through public sentiment was problematic. The torrent of gold seekers who flooded the country could hardly form a community complete with a "public opinion." But by the end of 1850 the Alta declared that "things have altered." Importantly, "a better class of persons have come like a flood into the country. Better morals have gradually gained strength and popularity."56
53 Alta, 20 November 1850 .
54 Ibid., 19 December 1850.
55 Ibid., 26 October 1850.
56 Ibid., 19 December 1850. 
This reported influx of "hardy, enterprising, industrious" people and good morals did not alleviate the felt need for vigilante action a few months later, but rather encouraged it. ${ }^{57}$ It made the middle class feel more powerful and willing to act as if from a position of strength. Movements toward reform or change are rarely, if ever, the result of a feeling of desperation and powerlessness, no matter what the protestations of the reformers might be.

The Alta found a source of this improvement in the "exhaustion of the enormously rich gold deposits." This produced benefits for California because
as the average returns for toil have decreased, the fact has produced an average increase of common sense, thrift, economy, and decency of conduct. ${ }^{58}$

The easy availability of gold promised immense rewards without a commensurate amount of work, and this, according to the Alta, was not conducive to the development of solid values. Middle class morals were associated the acquisition of wealth through regular work and deferred gratification. In California the acquisition had been associated with neither of these characteristics. But the depletion of easily accessible deposits of gold would allow the traditional relationship between work and reward to assert
57 Ibid., 30 December 1850.
58 Ibid., 19 December 1850. 
itself. If gold was losing its grip on San Francisco's psyche, it would create an opportunity for the merchants to assert their own. San Francisco seemed ripe for bourgeois restraint.

The other source of crime in California was straightforward. The Alta charged that California had become the "grand rendezvous" for the convicts of Britain's Australian penal colonies. 59 It was conceded that not every sydney immigrant was a convict, that some of them were fine citizens who might be enlisted in the cause of law and order. Indeed, Robert Senkewicz reported that Australians were more likely than their American counterparts to live in traditional family groups in San Francisco.60 Despite this, San Franciscans were convinced that expert criminals, late of the British penal colonies, had come to California and leagued together to bring ruin to the state.

There was an advantage in having an identifiable source of the crime that seemed to plague San Francisco (though some of it was admitted to be American in origin). It made it easier to combat. It was, after all, illegal to transport felons into the United States. The strict enforcement of these laws would help stem the influx of criminals. Those that remained operated in "systematic" and

59 Ibid., 25 February 1851.

60 Senkewicz, 79. 
"well drilled" gangs. ${ }^{61}$ It was expected that vigorous efforts to detect criminals and a few examples of punishment would convince the members of these gangs that California was no longer a congenial environment for their lifestyle.

\section{CALIFORNIA JUSTICE}

It was the perceived failure of the constituted authorities to either detect or punish offenders that built the momentum that culminated in the vigilance committee. The biggest complaint about the courts were the delays that occurred. The transient nature of California society meant that vital witnesses were unlikely to remain if trials took too long for their liking. The Alta maintained that, "Every man knows that in our state of society, a delay is equivalent to a mis-trial or acquittance."62

These delays were seen as a manipulation of the justice system by devious lawyers that were tolerated by judges of questionable merit. The ease with which accused criminals could obtain delays that ensured their eventual freedom made them contemptuous of the courts. They did not fear the authorities. In granting delays "crime has been fostered

61 Alta, 18 Dec 1850, 5 March 1851. A reference to a "regularly organized gang of these sydney thieves" appears on 22 Feb 1851 .

62 Ibid., 24 February 1851. 
instead of checked by the courts."63 The courts were thus partly responsible for crime:

Our courts, instead of being a terror to evil-doers, have proved themselves the protectors of villains, and thus encouragers of crime. This is a hard accusation, but it is true. 64

The constituted authorities were useless since they did not secure life or property. California needed "a system of legal adjudication, which shall be like the country, quick and effective." 65

The Alta claimed that it only desired a "revision of our present inefficient system" of laws.66 But this appeared to be posturing. It praised "Judge Lynch" in a fashion that was more convincing. The editor made an important distinction between lynch law and its "counterfeit rival Mob Law." Lynch law was undertaken in a sober, considered manner. And its record compared favorably with the regular courts in California:

Justice, fresh from the people, where blind excitement does not reign, is preferable, more honest, just and certain than when entangled like a grandfather longlegs in the webs of forty cunning spiders. 67

Government had failed. Another means of enforcing order was
63 Ibid., 23 February 1851.
64 Ibid., 24 February 1851.
65 Ibid.
66 Ibid., 5 January 1851.
67 Ibid., 13 October 1850. 
essential (according to the Alta) and the example of lynch law appealed to San Franciscans.

The brief experience of the gold rush led Californians to trust men more than laws. They found the governments that claimed to rule in California to be wanting and, inculcated with the American impulse for self-government, were unruffled by popular justice, including hangings. Yet many longed for the tangible consensus that conventional government and society represented. The desire for a settled order contrasted with the impermanence that distinguished most of California.

The men in California were not sure how best to face the future. Even if men wanted California to slow down and behave with perfect middle class deportment, it was not clear how this was to be accomplished. The Alta noted California was a place where men were tried by "wild freedom and loose liberty."68 To impose social order some Californians employed the lawless methods that symbolized the absence of conventional authority in their state.

68 Ibid., 16 April 1851. 
CHAPTER IV

SAN FRANCISCO: METROPOLIS OR MINING CAMP?

San Francisco and the mines were set in the same context of gold rush California. They shared and exchanged inhabitants, goods, and ideas. San Francisco was California's portal to the rest of the world. But it was the mines that defined California. Even the gold rush's metropolis was stamped with the orientation and attitudes of the mines.

Yet the city and the mines were set apart by their distinctive economic pursuits. The mines were characterized by irregular periods of work and frequent movement. San Francisco was the metropolis of the gold rush and the center of its commerce. Like the mines it had an overwhelmingly transient population. Even among the merchant ranks there was substantial turnover. But as businessmen the nature of their work contrasted with that of the miners. It was more regular. The orderly, harmonious society that was ideal for commerce would have difficulty in replacing the unrestrained atmosphere that thrived amongst the adventurers of the mines.

Yet even with this instability a merchant class was 
forming in San Francisco and was soon the leading catalyst for change in that city. These men wanted the institutions of government, uniform laws, internal improvements, and security for their property. They wanted conditions that would facilitate business. In the confusion of gold rush California a middle class came to power. But even as san Francisso grew to dominate California as its link with the outside world, the city could not escape the influence the mines exerted upon it.

THE DEVELOPMENT OF GOVERNMENT IN SAN FRANCISCO

The mining regions had, at best, limited use for normal forms of government. The relatively efficient systems of securing mining claims (which were often very informal) met the most prominent regulatory need of the miners. Drunkenness, rowdyism, and gambling, offensive to middle class sensibilities, generally did not interfere with mining life, and could be tolerated. Theft, robbery, and murder, which did interfere, were dealt with through informal majoritarian mechanisms, often referred to as the "law of the mines." Conventional institutions of crime control (courts, police, jails, and the like), were not well-suited to the ephemeral society of the mines as they required permanent governing bodies. Such permanence was elusive amongst a restless population intent only upon finding a big 
strike.

The pursuit of gold kept the attention of many from focusing on political developments, or the lack thereof. There were many other amusements to occupy Californians (and drain their pocketbooks). A good portion of these diversions (drinking, whoring, gambling, and general rowdiness), were not socially acceptable back home, or at least, the editor of the Alta thought this was so. In an editorial he suggested that California stripped away social restraint. "When the seekers of treasure left their old homes and associations in the United States and Europe, they were released from the regulating power of public opinion and law to a great extent...."1 Another time he lamented that men were "tried by the wild freedom and loose liberty which California has given so extensively to the world." California, he alleged, had an adversely affected some men:

The remark has frequently been made that the most sober, quiet steady people in the States, as soon as they have reached here, have, in a great many cases, become the reverse, drinking, spreeing, disorderly, gambling, and vicious.2

Whether vice and disorder in California were really more prevalent than in Chicago, New Orleans or elsewhere was not

1 Alta California (San Francisco), 18 June 1851.

2 Ibid., 16 April 1850. 
important to those with a middle class vision for san

Francisco. What was important was that the popularity of these activities in California revealed a population that did not share the middle class expectations of the Aita's editor and like-minded men.

There were, however, many Californians eager for familiar forms of government and society, none more so than the members of the Legislative Assembly of the District of San Francisco. ${ }^{3}$ These men were unhappy with the condition of government in 1849. The federal government had failed to provide civil government or a system of civil law for California. As a result, the military government which had been set up during the Mexican-American War, continued to operate with a motley collection of Mexican, American, and military forms of government. ${ }^{4}$ The president justified the continuance of the military government on the basis that Californians had given their "presumed consent" to the military government. ${ }^{5}$ Californians, at least those with business or political aspirations, were anxious to obtain a civil government that was either created or recognized by the federal government. The lack of civil government led to insecurity, both psychological and physical. Without a permanently recognized authority, land titles, for instance,

3 Ibid., 14 June, 19, 26 July, 9 August 1849.

4 Ibid., 11 January, 20 March 1850.

5 Ibid., 26 April 1849. 
would never be certain. Government was not particularly important to most of the legion that was descending on California hoping to find gold and return home rich men. But it was essential to those who planned to stay in California. Those who saw their future in California wanted to impose some order over it. ${ }^{6}$

In light of the lack of federal action some Californians contemplated the creation of their own government without prior approval from washington, D.C. A correspondent to the Alta California thought it unquestioned that,

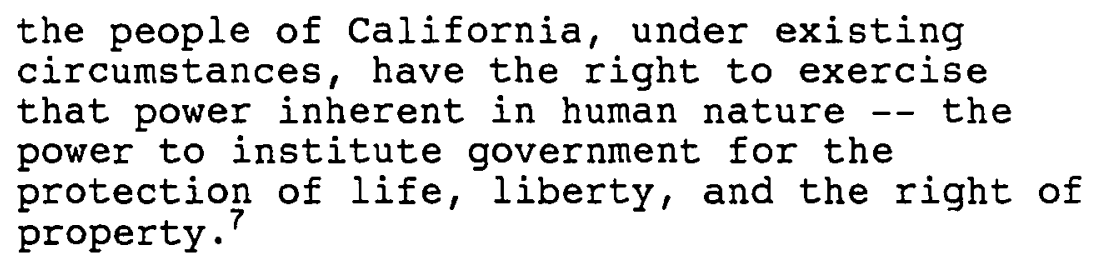

The president was abusing his executive power by insisting on the continued authority of the military government. The writer admitted that the president might proceed upon the grounds of "presumed consent" (as President Polk had done) so long as the people had not organized their own government.

The writer hinted at the future justifications of Californians for taking matters into their own hands.

6 Regarding attitudes toward government in California see David A. Johnson, Founding the Far West: California, Oregon, and Nevada, $1849-1890$ (Berkeley, Los Angeles, and Oxford: University of California Press, 1992), 15-40.

7 Alta, 26 April 1849. 
Action was required because of the peculiar situation in which Californians found themselves. The "existing circumstances" were such that it required men to exercise a power that existed in them in a state of nature. California was a special case, but their actions were sanctioned by universal truths.

Complaints were also directed at Congress both for its action and for its inaction: it levied taxes on Californians while affording them no representation. The Alta raged over this affront on the sacred Revolutionary principle of "no taxation without representation."

The only civil judicial officer in San Francisco was the alcalde. Though he was supposedly enforcing Mexican law, he had no familiarity with it and could not read Spanish. There were no higher courts to which appeals could be made. Civil government seemed to concerned San Franciscans to be "vague, uncertain, shapeless, and inefficient. "8

In February 1849, Californians, or some of them, took it upon themselves to pursue the creation of their own government and elected a Legislative Assembly of the District of San Francisco on their own initiative and without official sanction. The Assembly justified itself on the basis of the unusual circumstances brought on by the gold rush and the absence of civil government. The

$8 \quad$ Ibid., 9 August 1849. 
discovery of seemingly limitless deposits of gold had brought a jumbled mix of men to California, all imbued with a "feverish desire for fortune-making." This had produced an "anomalous" population. But "the state of our government is still more unprecedented and alarming. We are in fact without government." (emphasis original) 9 If Congress did nothing and the president supported a "despotic" military government, then it was the duty of the people to institute government themselves. The combination of these conditions led the Assembly to opine in an address to the people of the District of San Francisco regarding state government that, there is but one of two courses to take, either to remain in a state of perfect anarchy and confusion, or to form a government for ourselves. (emphasis original) ${ }^{10}$

California seemed to be in a state of nature, lacking the restraints of society. The constituted authorities (in Washington, D.C.) had failed to provide the mechanisms for instituting civil order. Californians would have to do it خhemselves.

They found legitimacy for such an action by the people in the Declaration of Independence. It was America's Revolutionary doctrines to which they looked for guidance. The address indicated how San Franciscans viewed the

9 Ibid., 26 April, 2, 14 June 1849.

10 Ibid., 14 June 1849 . 
exercise of popular sovereignty. It noted that there would probably be widespread apathy surrounding the vote on the effort to form a government. But this did not matter. All that mattered was the decision rendered by those who had actually voted.

If men remain at home and refuse to attend an election, it is their own fault, and the law will not presume that they opposed a measure, they did not vote against. (emphasis original) ${ }^{11}$

The words "those who vote" would become interchangeable with "those who act" for San Franciscans. In San Francisco, those who acted and acted effectively, would lay claim to the revered and powerful mantle of "the people." It illuminated the essential relationship between effort and popular sovereignty. The "people" were that portion of the population who took action.

The city's institutions were imperfectly established, and San Franciscans defied them for this very reason. It was every good citizen's desire, according to the Alta "that their property and their lives should be placed under the protection of some settled order of things."12 The institutions were too feeble to impose the sort of order which would give the city a sense of permanency.

Back in the nation's capital the slavery question seemed to leave Congress hopelessly deadlocked and unlikely

11 Ibid.

12 Ibid. 
to act to provide California with a civil government. The admission of California as a state would upset the balance of power between the slave states and the free states. This intransigence led to a call from the Assembly for local initiative to create such a government.

We have that question to settle for ourselves; and the sooner we do so the better. There is nothing to be gained by delay.... Prompt and determined action will secure us permanency and peace. ${ }^{13}$

In the tumult of gold rush California, patience was not considered a virtue.

When the Assembly acted to remove the alcalde who was, in effect, an official of the military government, General Riley, the military governor, charged that the assembly had usurped a power of Congress. The Alta disagreed in an editorial entitled, "A Revolution -- Its Progress." The assembly could not have usurped a power of Congress because it acted with the endorsement of the people: "this legislative body was formed by the action of the people of this District in mass convention assembled." The people had to act because "there was no other authority to which to appeal."14 The message was based directly on the revolutionary doctrines of the Declaration: California had no civil order; all authority had reverted to the people. The editor urged his readers to remember that the

13 Ibid.

14 Ibid. 
people had created the assembly because of "a sincere desire to preserve the lives and property of the community and to remedy the evils under which they had so long labored." It had been the inactivity of the military, or "de facto," government that had forced "the community to resort to Lynch law and such other expedients as the circumstances or necessities of the case required." The opponents of the military government did not wish "to overturn the law," but only "to establish and maintain public order and public good."15 This curious hypothesis, that the law must be defied to preserve order, appeared two years later in the June of 1851 when organized vigilantes imposed their own extralegal forms on the city.

About a month after this editorial, the editor commented on "The End of the Revolution." In response to General Riley's call for elections for a number of offices in the San Francisco and San Jose districts, the Assembly dissolved. But it defiantly asserted its authority had been legitimate because it had come directly from the people. They stressed that it was the creation of the Assembly and its actions that prompted Governor Riley to call for elections. Without the Assembly the absence of government would have continued. Extralegal action had been necessary to compel the government to act. The "revolution" had ended, said the Alta, because the Assembly nobly stepped 
down rather than force a "collision" with the military

government after the call for elections. ${ }^{16}$ San

Franciscans, when they became vigilantes in 1851, recalled these exact themes.

The circumstances surrounding the legislative assembly in San Francisco reprised again in the city. The sense that there were injuries requiring redress brought a portion of the citizenry to action. The extralegal nature of the action was justified on the basis of the peculiar circumstances in California, the exigencies of the situation, the inaction of the authorities, and the notion of popular sovereignty. The lack of strong institutions provided a context in which the authorities had inadequate power to resist any sizable collection of men with a purpose.

Another example of resistance to the constituted authorities occurred in February 1849. Under the heading, "Gross Outrage," the Alta reported that the alcalde had issued a warrant for the arrest of a man who had severely criticized the condition of the jail. The sheriff and his posse "made forcible arrest," of the offender, Mr. Everhart. Upon being brought before the alcalde, Everhart demanded a trial or a written discharge. When the alcalde refused to provide either, Everhart left. Under orders from the alcalde, the sheriff and his posse chased Everhart, followed

16 Ibid., 19, 26 July, 9 August 1849. 
by a crowd of onlookers. Amid the confusion Everhart asked the crowd for protection.

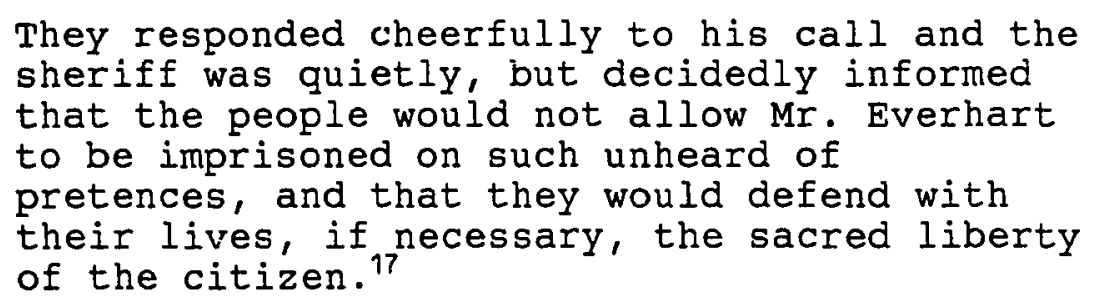

Everhart was allowed to leave. No action was reported to have been taken against the defiant crowd or Everhart. The institutions of authority, the alcalde and the sheriff, were not only inadequate to resist the crowd, but were also unable to enforce their will once the crisis had passed. It was clear where the real power in San Francisco resided: in groups of men willing to take a stand.

The residents of San Francisco did not appear to have any particular regard for officials. The Alta wrote approvingly of this action as having demonstrated "courage and decision" in response to an "extraordinary occasion." The paper hoped that the same sort of "resistance to oppression and wrong" could be sustained "until the town of San Francisco shall be governed by wise laws and worthy executive officers."18 Apparently, a determination of the adequacy of a law and its enforcement could be made in a spontaneous manner.

17 Ibid., 15 February 1849.

18 Ibid. 
THE HOUNDS INCIDENT

In July and August of 1849 San Francisco had an experience which would provide a direct precedent for later vigilante activities. A group of men known as the "Hounds" or "regulators" became the target of the community's wrath. The Hounds had initially worked rounding up seamen who had deserted ship. Shipmasters paid to have their wayward seamen, who hoped to become miners, returned to them. But in time the Hounds became bolder and uninhibited. They apparently strongarmed restaurateurs and barkeepers, and generally acted as bullies. On a sunday night they went on a rampage in the tent-city on Telegraph Hill inhabited by Chilean immigrants. There a series of robberies, assaults, and acts of arson took place. ${ }^{19}$

In response, the alcalde made a call for the citizens to gather, which resulted in the largest public meeting in San Francisco to that time. ${ }^{20}$ A quasi-official force of 230 men then pursued and captured 17 members of the Hounds and confined them aboard a ship in the harbor.

19 For the Hounds Incident see Roger W. Lotchin, San Francisco, 1846-1856: From Hamlet to City (Lincoln, Nebraska and London: University of Nebraska Press, 1974), 190-191; Mary Floyd Williams, History of the San Francisco Committee of Vigilance of 1851 (Berkeley, California: University of California Press, 1921; reprint, New York: De Capo Press, 1969), 105-109; Kevin J. Mullen, Let Justice Be Done: Crime and Politics in Early san Francisco (Reno and Las Vegas: University of Nevada Press, 1989), 55-61.

20 Alta, 4 August 1849. 
A trial was arranged which was presided over by three judges: the alcalde and two men chosen in a public meeting. The two "citizen-judges" lent a legitimacy to the proceedings which the alcalde, had he acted alone, would not have commanded. The extra-legal police force did not immediately disband. Some men continued to act as a night patrol. One of the prosecutors, Francis J. Lippitt, spoke of "men giving up their business and industrial pursuits to come forward and see that the wheels of justice are not impeded."21 There was no clear-cut distinction between duly constituted authority and popular authority.

Lippitt charged that the Hounds had committed treason against the community. "The acts and outrages I allude to are the result of a conspiracy -- a systematic attack upon the lives and property of this community."22 The charges of assault with intent to kill, robbery, and riot were only overt manifestations of an underlying and sinister cabal. The reason for the lesser charges, lippitt maintained ominously, was that there were "influential men -- who lean to the side of the prisoners, and who throw obstacles in the way of justice."23 Such powerful opposition to social order justified strong action by the community. Considering the influence of the allies of the Hounds,

21 Ibid.

22 Ibid.

23 Ibid. 
the charges that could be legally made against them could only be a rough measure of their transgressions against the community. The defense claimed that San Francisco lacked standards of law and thus there were no regulations that restrained action. Lippitt responded that the Hounds had acted in defiance of "uniform principles of natural justice." It was not necessary to have a statute to inform ordinary men of these standards of conduct. Such acts of depravity required "a warning to future transgressors." It was through a "certainty, not severity of punishment [that] society [could be] purified of crime."24 Four of the Hounds were sentenced to prison and three others fined and ordered "to keep the peace for twelve months."25 The sentences could be only imperfectly carried out, partly due to the lack of a penitentiary.

Roger Lotchin argues that the vigilante actions in the Hounds affair filled "a legal vacuum."26 The connection to later vigilante actions, when a legal mechanism was in place, is in this regard somewhat tenuous. But there were important similarities. These were, first, the way in which citizens were involved in police and judicial activities. Second was the conception of the offenses as part of a larger attack on the community, along with the suspicion of

\footnotetext{
24 Ibid.

25 Ibid., 16 August 1849.

26 Lotchin, 199.
} 
the criminals being connected to powerful elements in the city. Finally, there was the question of justice, as opposed to legal forms, which required immediate action. It was in this regard a moral, not a political, question.

San Francisco reverted to its usual routine after the Hounds incident. The volunteer night patrol faded away. Civic responsibility was something most San Franciscans were willing to leave to someone else.

\section{AMBIVALENCE TOWARD GOVERNMENT IN SAN FRANCISCO}

By October 1849, the editor of the Alta discerned a pattern emerging in the city's civic life. He noted that determined action by the citizenry in creating the Legislative Assembly had resulted in the town's interests being "vigilantly guarded." But for want of revenue and interest from the citizens, the assembly (i.e. the government) had been unable to prevent or stem the marauding activities of the Hounds. This episode roused good citizens from their "lethargic sleep" and they "arose as one man to quell tumult, arrest offenders of justice... and restore tranquility and law." The editor hoped that a revenue measure passed, because it would fund government services that would render it unnecessary for the citizenry to personally combat criminals like the Hounds. ${ }^{27}$ But in the 
absence of such effective government, San Franciscans still had citizen action as a model of implementing social control.

The following March (1850) the Alta continued to complain about the state of government. While San Francisco had grown larger and richer it was still governed in an uncertain manner. The paper complained that the mixture of Mexican law and common law was unwieldy and difficult to make sense of. Still, much of the blame lay with the town council and those who had elected them. The people "are invested with ample powers, if judiciously exercised, to work out the greatest good for our suffering municipality."28 But San Franciscans were not particularly interested in the everyday business of government.

While commenting on the activities of political parties in San Francisco the Alta identified the source of this lack of interest: the yearning for gold. There would be little interest in party politics, or any sort of politics, for that matter, "so long as Mammon rules the day."29 San Franciscans did not define themselves by their civic participation. They defined themselves by their individual interest.

When San Franciscans did participate in politics they did not do so politely. In response to the perception of

28 Ibid., 20 March 1850.

29 Ibid., 4 March 1850. 
high taxes in June of 1850 a group of men amongst those gathered at Portsmouth Square hissed and groaned at the town council. The Alta condemned this "a deliberate insult to those who had been elected at the ballot box" and called it the "action of a mob." (emphasis original) 30 It was certainly the former and quite possibly the latter, but it was how San Franciscans tended to discharge their public responsibilities.

This same excitement over taxes produced a series of "indignation meetings." The Alta recognized such assemblies as a tradition in San Francisco. "Indignation" had been "frequently manifested in this community, at each political change in our city affairs." (emphasis original) The editor assailed these methods as ineffective: "The people have complained, they have remonstrated, they have assembled in indignant mass meeting[s], and they have resisted," but they had not established, or funded, a capable government. ${ }^{31}$

This was because they did not really care to do so. The sporadic character of public life in San Francisco resulted from the importance that its residents placed on it. San Francisco was overwhelmingly composed of young men hoping to get rich quickly or at least to have a good time. That there was a real chance to do both made men's detachment from routine political functions unremarkable.
30 Ibid., 5 June 1850 .
31 Ibid., 8 June 1850 . 
Most men in San Francisco did not view the mundane work that was part of conventional politics as profitable or enjoyable.

San Franciscans had come to view civic responsibility as episodic in nature. Men were either too busy seeking wealth to perform civic duties regularly or simply indifferent. In some ways the spasmodic political life of San Francisco was not much different from other parts of America. A mixture of independence and acquisitiveness disposed Americans to attend to their own affairs at the expense of community involvement. The heritage of popular sovereignty and the substantial power it conferred on individuals, especially as members of a group, gave men a natural sense of authority. Therefore, it was not particularly surprising that men could alternate between apathy and the assuredness of a sovieign. The alternating indifference and indignation was foreseeable. The residents of San Francisco and their compatriots in the mines, stood in stark contrast to the civic humanist tradition in which the individual presupposed the community. In Cali.:ornia $t_{\mu}$ commuity not only presupposed the individual but was subservient to him.

In San Francisco there was an ambivalence toward the nascent institutions of government. Though distinct from the mining regions (and with some pretensions to superiority) the city could not escape the defining context 
of the mines in California. Most Californians lived in the mining regions and most San Franciscans were headed for, coming from, or had been in the mines. Virtually all the "institutions" of government in the mines were irregular collections of individuals. It was widely accepted that the "law of the mines" and extralegal action were appropriate to that region. To a large extent San Franciscans had operated in a similar manner. Institutions of government seemed to draw their power mostly from the vacuum left by the absence of popular action. Even so, the commercial predisposition of San Francisco gave rise to a desire among some segments of the population for a more regulated and systematic society than that which existed in the mines.

The demography of San Francisco made this problematic for the same reasons as it was in the mines. The young male population was unencumbered by the usual foundations of social order: family, church, employer, and capable government. San Francisco's own experiences had reinforced an inclination to look outside legally sanctioned modes of political expression.

Born of and for trade, San Francisco was the quintessential commercial city. At the same time it embodied the gold rush with its uncertainty, impermanence, and incomparable potential. Most of the men residing in the city were on their way to or coming from the mines. The city had something of the character of a huge, but idle, 
mining camp with a nucleus of settlers: the merchants. This commercial class in San Francisco was comfortable with both conventional middle class forms of community building and the extemporaneous methods that had been improvised in the mines. Thus political life in the city displayed aspects of these dissimilar processes of governance. As concern over crime in the city increased, some san Franciscans blended these contrasting styles in an effort to impose order. 


\section{CHAPTER $V$}

\section{SAN FRANCISCO VIGILANTISM: THE EXCITEMENT OF 1851 \\ CRIME IN SAN FRANCISCO}

Signs of dissatisfaction abounded in San Francisco as 1851 began. The authorities and courts seemed incapable (or unwilling) to curb what many perceived to be an escalation in crime. Fires menaced the city. San Francisco appeared to be undisciplined and maladministered. The great commercial city of the Pacific Coast lacked the dignity and bearing that befitted it. Seeking order, a group of san Franciscans turned to the means prevalent in the mines for this task: direct action.

Frustration with the authorities was coupled with a real increase in crime. While the more expansive claims of some apologists for the vigilantes, that there had been 100 or more murders in San Francisco in the year preceding the committee's formation for instance, are not true, there was an increase in predatory crime. ${ }^{1}$

Kevin J. Mullen has documented the reports of criminal homicide, robbery, and burglary for San Francisco between

1 Kevin J. Mullen, Let Justice Be Done: Crime and Politics in Early San Francisco (Reno and Las Vegas: University of Nevada Press, 1989), xv-xvi, 26-30. 
July 1849 and December 1852. He found that reports of criminal homicide rose from three for the first six months of 1850 , to thirteen for the second half of the year, and fell to nine for the first six months of 1851. Robbery showed a similar trend from two, to eighteen, and back down to nine. Though both homicide and robbery fell in the first half of 1851 both were still at levels far higher than they had been a year earlier. Burglary, however, rose precipitously from four in the first half of 1850 , to fortynine in the second half of the year, and fifty-three to start out $1851 .^{2}$

Burglary was insidious because it was not as easy to avoid as many other crimes. Keeping respectable company and avoiding saloons and games of chance drastically lowered one's chances of becoming a victim of violent crime. But peaceable citizens, especially those who had achieved material success, were likely targets for burglars. Therefore, the increase in burglary is important in understanding the threat of crime felt by the middle class citizenry of San Francisco. The Alta reported that chicken stealing had become common during the winter of 1850-51.3 Minor crimes like chicken stealing might not endanger lives, but they did widen the circle of those affected by crime and magnified the sensation that crime was out of control.

\footnotetext{
2 Ibid., 110, 127, 128, 129-130, 216, 228-230.

3 Alta California (San Francisco), 15 February 1851.
} 
In a similar vein, Bryan white has compiled figures regarding cases before the Recorder's Court in San Francisco for 1851. The Recorder heard civil cases that involved amounts of less than $\$ 500$, held initial hearings on some criminal cases, and decided whether these should be referred to a higher court. Its jurisdiction also covered city ordinance violations, such as drunkenness or disorderly conduct. As such, the Recorder's ledger serves as a history of the enforcement of middle class values of sobriety and civil behavior. It also documents the kinds of crimes what were likely to affect ordinary people. White found that the reported crimes per month increased nearly 55 percent from January to February 1851. The rate remained high (relative to January) through July. In light of these figures it could be expected that many San Franciscans felt their city lacked order. ${ }^{4}$

For citizens who longed for San Francisco to be an orderly city inhabited by individuals who exhibited selfcontrol, the beginning of 1851 imperiled their vision. Instead of becoming more settled, the city seemed to be slipping into an abyss of debauchery. The rowdiness and aggressiveness that characterized gold rush society seemed to be triumphing over moderation. Frightened by the prospect that San Francisso's condition could become an

4 Bryan White, "Crime in San Francisco, 1851," (unpublished research paper, Portland State University, n.d.), passim. 
incorrigibly dissolute, the city's middle class hoped to reform the city in conformity with their aspirations for a disciplined, restrained city where commerce and conventional social forms could flourish.

\section{THE JANSEN AFFAIR}

San Francisco's middle class felt especially endangered in February 1851, after a respected merchant, C. J. Jansen, was robbed and seriously injured in his store. Two men were arrested. A conflict quickly escalated between a crowd, who wished to hang the accused or try them themselves, and the authorities, who were determined to see the legal process through. Ultimately a court, the officers and jury of which were chosen by the assembled men, tried the pair, but they failed to reach a definite verdict. After the verdict the disappointed crowd made several attempts to seize the prisoners. The police, with the help of 250 volunteers, turned back these efforts. Eventually the prisoners, Robert Windred and James Stuart (really Thomas Berdue), were turned over to the authorities, tried and sentenced to prison. Although the Jansen affair did not lead to the immediate formation of the vigilance committee, it was a direct antecedent. 5

5 On the Jansen incident see Mullen 123-128; Mary Floyd Williams, History of the San Francisco Committee of Vigilance of 1851 (Berkeley, California: University of 
The Alta took the opportunity provided by the Jansen excitement to contrast the effectiveness of the summary methods of the mines against the worthless legal machinery of San Francisco. In the mines, the newspaper editorialized, a criminal

usually receives a short shrift and a long rope, or stripes upon his back sufficient to remain as a lasting memento of summary justice. In San Francisco, however, it has become almost proverbial that there is no punishment for crime, no legal protection for peaceable citizens. ${ }^{6}$

The Alta compared the courts with a British ministry which had just been given a vote of no confidence by the people's reaction during the Jansen affair. The action of the people had been a clear manifestation of their wishes.

The people, outraged beyond endurance, have calmly, not with riot, denounced the pseudo embodiments of law and order, called administrators of justice. There is now not one particle of respect felt for the officers of the courts.

It was hoped that an "assemblage of five thousand citizens" would induce the courts to more energetic punishment of criminals.8 The Alta reported that it had received

California Press, 1921; reprint, New York: De Capo Press, 1969), 170-176; Robert M. Senkewicz, Vigilantes in Gold Rush San Francisco (Stanford, California: Stanford University Press, 1985), 2-4.
6 Alta, 21 February 1851.
7 Ibid., 24 February 1851.
8 Ibid., 23 February 1851. 
"numerous" letters from citizens who insisted the authorities step aside if they would not put a check upon crime. The writers suggested direct public action to make an example that would address the problem of crime. ${ }^{9}$ It did not seem to matter that it was not a regular court, but a popularly selected court, that had failed to convict the men suspected of the Jansen robbery.

The Jansen affair exposed an ambivalence in the public mind regarding the administration of justice in san Francisco. On one hand, the example and personal experience many San Franciscans had of the mines led them to endorse the abrupt and popularly driven methods of social control practiced there. But doubts about the appropriateness of lynch law to San Francisco worried residents as well. San Franciscans were torn between the ethos of gold rush California and their image of themselves as inhabitants of a great city where the roughness of the mines did not belong.

\section{THE CHAIN GANG}

After the excitement surrounding the Jansen affair had died down the Alta undertook a new crusade: the establishment of a chain gang. It was, argued the editor, a mode of punishment befitting a settled city. Criminals would be forced to toil and thus compelled to meet the

9 Ibid., 21 February 1851. 
middle class expectation of an industrious citizenry. Similarly, the Alta had called for a vagrant law. ${ }^{10}$ The chain gang was the ultimate middle class punishment. Laziness was considered a chief characteristic of criminals. Confinement was hardly punishment to these laggards. They were able to lounge all day and were provided with food and shelter. The criminals" "horror of hard work" made the chain gang the "most severe punishment" imaginable. Should inmates refuse to work, "apply the lash or starvation."11

The city council approved a chain gang during the Jansen excitement. But it turned out that the council did not have the authority to institute such punishment. The court of Sessions did, however, and obliged by establishing a chain gang. 12

The Alta found that the chain gang helped in "restraining crime," more so "than would one or two executions."13 The paper also credited the public demonstrations during the Jansen affair with having a similar effect. The approbation for the chain gang and the approval of the near-lynching of the men accused of the Jansen robbery illustrated the duality in the Alta's and san Francisco's thinking about criminal justice. The chain gang

10 Ibid., 5 January 1851.

11 Ibid., 11 March, 25 Feb 1851.

12 Ibid., 27 February 1851.

13 Ibid., 10 April 1851. 
embodied middle class expectations of order and industry. Iynching seemed to be the abandonment of them. In gold rush California, however, lynching could also be very middle class.

The contention that crime had decreased was borne out ty ifullen's research for robbery and murder, but not for burglary. Still missing in the minds of many san Franciscans were a satisfactorily speedy system of adjudication and visibly effective punishment of those convicted. "Let us but have a system of quick adjudication in criminal trials and an additional security will be obtained," averred the Alta. ${ }^{14}$ The proponents of civil order felt improvements had been made but were not satisfied that the authorities were energetic enough to enforce order.

\section{JAIL BREAKS AND FIRES}

Potential vigilante leaders gained a level of confidence due to the fairly successful resistance of the crowd to the authorities during the Jansen affair. The institution of the chain gang was a victory for middle class values. But if these events gave heart to the merchants, they were alarmed by a number of escapes from the city jail, a series of fires (which they perceived to be caused by arson), and the relatively high rate of burglary.

14 Ibid. 
Between April 9, and June 3, 1851 there were seven separate escapes from the city jail and another attempt (which the police thwarted), or a rate of about one escape every week. At least 37 prisoners escaped during these jail breaks. Throughout the Alta wondered how the prisoners obtained tools to break out of jail and how the escapes were effected when several police officers were supposedly guarding the prisoners. (In the wake of the escape on May 9, four officers were fired for negligence.) A criminal's "safest and cheapest course" when arrested, claimed the Alta, was to be convicted and sent to jail from which he could easily abscond. The Alta grumbled that "there seems no hope of punishment." The paper also demanded that the partially built jail be completed. The escapes and the lack of an adequate jail led the Alta to the conclusion that "the branches of government, judicial, aldermanic, and poiice a.:e all of a piece -- just good for nothing."15 San Franciscans' most readily available alternative to their supposedly worthless government were the methods employed in the mines.

In 1849 and 1850 San Francisco experienced three disastrous fires. ${ }^{16}$ Each of them destroyed large parts of the city. Fire was a common danger in the nation's urban

15 Ibid., 9, 24 April, 1, 2, 3, 4, 7, 9, 10, 14, 20, 26, 31 May, 3, 6, 7 June 1851.

16 Lotchin, 174-175. 
areas during the nineteenth century. San Francisco, built of wood and lacking a water system equal to the task of fighting fires, was particularly vulnerable to ruinous fires. The city's residents were understandably sensitive to the destruction fire could bring. Historians have discounted arson as the cause of most of the city's great fires. But for many San Franciscans it was an article of faith that arsonists set the fires that laid waste to large parts of the city. ${ }^{17}$

The incendiary was among the most sinister images a san Franciscan could conjure in his mind. The Alta found it "difficult to conceive of the utter moral prostration of the human mind which must exist in the incendiary." It was a desire for gain, theft committed in the confusion of the fire, that supposedly actuated the incendiary. The arsonist and his confederates, it was believed, operated in organized gangs, setting fires that they might reap their bounty while honest men fought the blaze. The death penalty was considered appropriate for such crimes. ${ }^{18}$

The day before the Jansen robbery a fire was discovered and extinguished. The Alta thought it was "undoubtedly" the result of arson. ${ }^{19}$ Then, in early May, the fourth great fire ravaged San Francisco. Perhaps as much as one-fourth
17 Senkewicz, 72-75; Mullen, 83; Lotchin, 176-177.
18 Alta, 24 January 1850.
19 Ibid., 20 February 1851. 
the city and three-quarters of the business district were destroyed. Between 20 and 100 people died. ${ }^{20}$ Many were burnt out of their businesses. In addition to the losses stemming from the fire itself, "crime seemed to run riot throughout the city."21 Initially the fire was attributed to an accident. But shortly the Alta's contention that the fire had been set "by an incarnate fiend for the purpose of robbery" gained credence. ${ }^{22}$ The horrible effects of the fire were an understandable cause of consternation amongst the city's residents.

In mid-May two more "attempts" to set fires were reported, one being aimed at the city hospital. "This attempt to fire the city seems to now be of nightly occurrence," the Alta complained. ${ }^{23}$ Two more "attempts to fire the city," were controlled in early June. ${ }^{24}$

The monstrous menace that fire posed to the city's well-being (and even its existence), the perceived incidence of crime, and the sense that both were being orchestrated by a class or organization of criminals make understandable the urgency felt by San Franciscans. They were exasperated by authorities who seemed incapable of remedying the situation.

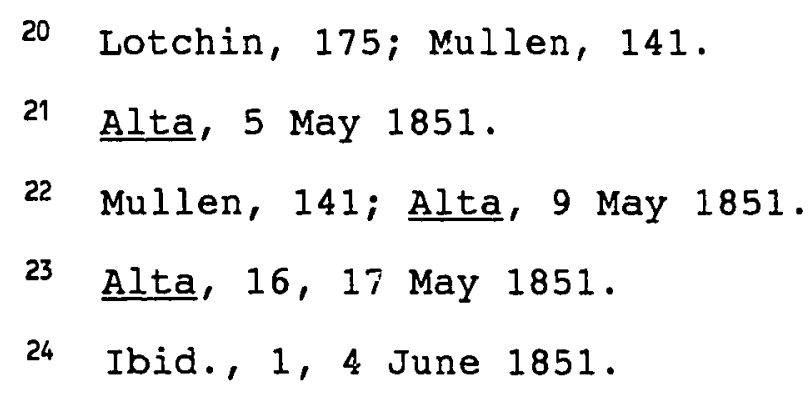


Hopes that San Francisco could be a peaceful, commercial city seemed to be slipping away.

By mid-May the supposed efforts of this criminal element to burn down the city "show plainly that some more extensive and efficient mode mist be adopted to secure" the city from further fires and crime. A "large portion" of the police, the Alta charged, "offer a protection to, rather than a check upon the disorderly and vicious." In light of this the only answer to these threats to the city was "a volunteer police."25

A volunteer night patrol was formed. The group was led by prominent merchant F.W. Macondray and received the official sanction of the city government. It had about 100 members who patrolled the streets. The volunteer police were authorized by a city ordinance and its officers sworn in by the mayor. George schenck, one of the volunteer policemen and later a vigilante, said the patrol "may be said to be the origin of the Vigilance Committee of 1851." Mary Floyd williams said this was "not exactly substantiated by other accounts, but it indicates one of the influences which led to the formation of the Committee of vigilance." Not surprisingly, many of the volunteer policemen became vigilantes. ${ }^{26}$ The volunteer patrols apparently continued into July, but the extent of their activities was not

25 Ibid., 19 May 1851.

26 Williams, 180-181; Alta, 19, 20 May 1851. 
reported in the Alta. What association it may have had with the vigilance committee, if any, is not known. ${ }^{27}$ Its sanction by the authorities demonstrated a congeniality to (or an inability to resist) citizen involvement in law enforcement in San Francisco.

OUTRAGE

Despite this apparent congeniality between the citizens and the authorities of the city, events were coming to a head. On June 2, an Australian immigrant, Benjamin Lewis, set fire to a boarding house after being evicted and was arrested for arson. During a hearing he was nearly lynched in court after a false alarm of fire. Later, the unpopular Judge Levi Parsons quashed the indictment against Lewis on the grounds that the grand jury had been illegally convened. ${ }^{28}$ Another Australian caught burglarizing a store was nearly hung by a crowd before they relinquished him to

27 Alta, 14, 20, 22, 25, 26 June, 11 July 1851.

28 Judge Parsons had aroused popular indignation with his treatment of newspaper editor William Walker and by instructing the grand jury not to return indictments except when the evidence was strong enough to bring a conviction in a jury trial. The San Francisco Herald (Walker's paper) charged that this was tantamount to instructing the grand jury "to aid the escape of criminals." Parsons's action only hardened the beliefs of those who suspected the authorities lacked the desire to fight crime. Supra, chapter 3, 85-86; Williams, 177. 
the custody of the police. ${ }^{29}$ On June 6 , the Alta reported that Marshal Crozier closed police records to the press. ${ }^{30}$ Two days later a communication was printed in the Alta from "Justice," purported to be from "one of our most respectable firms." "Justice" called for the formation of two committees. A "committee of safety" would board ships that hailed from the British penal colonies to ensure that only "respectable and honest men" disembarked. A "committee of vigilance" would locate criminals still in the city and give them five days to leave. A "war of extermination" would be undertaken against those who remained. The Alta approved of these suggestions and remarked that no one need be injured or killed; undesirables need only stay out of san Francisco. ${ }^{31}$

If such action seemed illegal or insurrectionary the Alta reminded its readers that the people "are the original source of power. They are the law." Written laws were only an "expression of their will" and could be changed or discarded when the authorities failed to protect the people. 32 This was powerful testimony to a sense of popular sovereignty.

On June 8, another fire was contained. The Alta found

29 Mullen, 146.
30 Alta, 6 June 1851.
31 Ibid., 8 June 1851.
32 Ibid.


in it an ominous lesson: "This could not possibly have been the result of accident and it is rendered positive and beyond a doubt, that there is in this city an organized band of villains who are determined to destroy the city." The problem of crime had been "talked and written and thought" about long enough, lectured the Alta. "Let a public meeting be called immediately, and let some simple but determined plan of action be agreed upon, by which we may rid ourselves of the incendiaries and burglars who infest our city."33

The Alta chided San Franciscans for their lack of action. "We doubt if there is spirit or public spirit enough among our people to even reprimand one of these throat slashers, were he caught in the act of strangling a child or setting fire to a church." The authorities had failed and needed direction from the people, wrote the Alta's editor. "There is something needed on the part of the people. They must give tone to the action of the courts, and must show and exercise some interest in the public welfare."34 Somehow, the summary methods of mining justice ought to be used to invigorate the conventional modes of social control in the city.

Shortly after two o'clock the next morning a sydney immigrant, John Jenkins, was dead, hanging by his neck from the gable of the old adobe customs house in Portsmouth

\footnotetext{
33 Ibid., 9 June 1851.

34 Ibid., 10 June 1851.
} 
Square. The popular temper had boiled over. The people had shown the courts what to do.

Jenkins had been caught spiriting a strorgbox from the rooms of a merchant. Instead of delivering him to the police, his captors took him to the rooms of the newly formed Committee of Vigilance. The prearranged signal to summon the committee, two tolls of the city's fire bells at one minute intervals, was made. Committeemen, armed with a prearranged password, gained entrance to the building. As word of the Jenkins "arrest" spread, spectators filled the streets. After a secret trial, Jenkins, reputed to be an ex-convict and hardened criminal, was sentenced to death. (A sentence of death for grand larceny was an option available to juries in California at this time.)

An armed guard of vigilantes marched the condemned man through the streets to his execution. Attempts to rescue Jenkins, by his friends and the police, were forcibly resisted. Among the crowd that witnessed the hanging perhaps as much as a third of those present opposed it according to Ira Cole, an opponent of the vigilance committee. But a clear majority of the crowd approved of the execution. ${ }^{35}$

In juxtaposition to the gravity of the hanging, the activity in the nearby gambling halls and saloons went on.

35 Williams, 215. Cole later attacked a member of the committee, see Williams, 321. On the Jenkins hanging see Williams, 208-217; Mullen, 158-166; Senkewicz, 4-5, 83-84. 
One witness related how he and his companion, unsure whether a hanging would actually take place, debated whether to go eat or wait for the possible execution: "so we argued the case -- oysters vs. Hanging -- and after an able discussion on both sides, Hanging got a verdict in his favor."36 Apparently, lynching was not out of place in San Francisco.

JUSTIFICATIONS FOR THE VIGILANCE COMMITTEE

In the next few days the Alta discussed the actions of the committee as earnest exhibitions on the part of reflective, public-spirited men. It applauded the "calmness and deliberation" that had characterized the committee's work. ${ }^{37}$ But the informality with which the event was regarded by some of the crowd revealed an aspect of popular justice that worried the Alta, and even some of the vigilantes. Mass public demonstrations, without the sage guidance of the city's best men, could easily degenerate into mob action and disorder. Curiously, the paper was able to conceive of the will of "the people" and the leadership and action of "the few" as compatible concepts. The language of liberal majoritarianism was colored by classical rhetoric regarding capable, elite leadership. Vigilantism

36 Marysville (California) Herald, 14 June 1851.

37 Alta, 12 June 1851. 
was a fearsome assertion of the popular will. It implied an uncontrollable power, the perilous essence of popular sovereignty.

The edition of the Alta which appeared on the day of Jenkins's hanging (and which had been written before the hanging took place) reported the formation of a "secret organization," the vigilance committee. It reflected on past attempts at lynching in San Francisco calling them "extremely farcical." However, the incidents pointed to "the existence of a spirit that cannot much longer be smothered and subdued." This desire to wreak vengeance on criminals "will break out ere long, and woe unto those who provoke it." This spirit, when it found expression in a leaderless mob, was weak and easily quelled. But with organization and leadership, "the next affair of this kind will be of a different character."38 popular expression required able leadership to implement its will. The question for the Alta seemed to be whether, once awakened, this spirit could be contained.

Initially, the committee was a secret organization. In the wake of the Jenkins hanging, however, its membership became more or less public knowledge. And membership was considered a badge of honor. The coroner's jury investigating Jenkins's death found that he had met his demise at the hands of "an association of citizens, styling

38 Ibid., 11 June 1851. 
themselves a Committee of Vigilance."39 Nine vigilantes were named by the coroner's jury. The next day 180 members of the committee signed a communication to the city's newspapers claiming responsibility equal to those named by the coroner's jury. 40

"The authorities are placed in a very serious dilemma," opined the Alta. It was clear that the vigilantes had broken the law, but the prosecution of those named by the coroner's jury would result in "nothing less than riot and bloodshed."41 The authorities had brought the difficult situation on themselves by failing to protect the public from dangerous criminals: "the people were compelled for the safety of their lives and the protection of their property, to take the law into their own hands, and mete out a terrific punishment to the guilty."42

Yet, while the Alta spoke of the action of "the people" it recognized that it was really the act of the vigilance committee. It was not yet clear that the vigilantes had been sanctioned by the people: "It seems to have become a question as to whether they will or will not be sustained by the community." 43

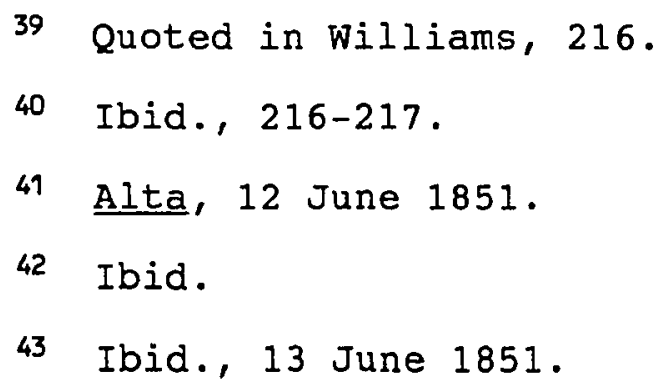


Although the Alta seemed to insist on a popular sanction for the vigilance committee, it equivocated on the subject of popular action. Recognizing that "sage and lengthy" arguments had been made against an assumption of power by a group of men, the Alta replied that it was a "well known fact that nothing can be accomplished by a movement of the mass." Efficiency demanded that the enforcement of the law be undertaken by "the few, "either the regular authorities or the vigilance committee. ${ }^{44}$ The vigilance committee's legitimacy was defended by the Alta and others on the basis of its being composed of the best or leading men of the city. At the same time the Alta continued to insist that the actions of the vigilance committee were the expression of the will of the citizenry. When the authorities fail to protect the public "the people are compelled to take upon themselves the duty of self preservation." The "community must preserve and defend itself. " 45

The vigilantes were the agents of the community, preserving and defending it. The people's role was to validate the actions of the vigilantes. The notion of popular sovereignty championed by the supporters of the vigilance committee in San Francisco was not a pure and unmediated one. There was something dangerous and untamed

\footnotetext{
44 Ibid.

45 Ibid., 14 June 1851.
} 
about authority which flowed from and was physically enacted by the people without the "filter" of worthy men, elected or self-appointed. Even in egalitarian gold rush San Francisco the American belief that some men are better suited than cthers to lead ran deep. Following the hanging of Jenkins the AIta felt compelled to justify it not to Californians (who presumably understood the necessity of such methods), but to the residents of the East Coast. The paper worried that Easterners would not understand the unique circumstances (the "evils") which were present in California and thus made summary justice imperative. ${ }^{46}$ This need to explain and justify vigilantism illustrates the doubts that some san Franciscans felt about the hanging. Lynch law seemed natural in the context of the mines (and this context heavily influenced San Francisco), but there was a certain level of discomfort, behind all the brave talk, that such methods were being employed in their "emporium of the Pacific."

In an attempt to justify the employment of vigilantism in San Francisco the Alta editorialized on the conditions that had brought it about. California had experienced an extraordinarily large and heterogeneous immigration, which included a large number of "the most daring, depraved and reckless men." For some time Congress failed to extend 
civil government to California, leaving it in a state "nearly bordering on anarchy." When civil government was instituted it proved to be incompetent and corrupt, particularly in the area of criminal justice. The police and the courts were either inept or in collusion with the criminal element. Prisons offered little resistance to convicts wishing to escape. The "whole machinery of government" was a complete failure. ${ }^{47}$

The Alta then addressed five objections which had been raised regarding the vigilance committee's handling of the Ionkins case. The paper's reasoning illuminates many of the assumptions of, and rationale for, the comnittee. First, why had Jenkins not been turned over the authorities? Because "experience had conclusively demonstrated" that even if Jenkins were tried and convicted he would "easily escape punishment." Second, why was the trial conducted in secret? "Because if good were to be accomplished, it could only be accomplished by the few. If the multitude were participants, nothing but confusion, disorder, and irresolution would result." Third, why was the death penalty imposed? "Because it was honestly believed that such action was necessary for the purpose of intimidating and restraining other offenders." Fourth, why was there no delay in carrying out the sentence, especially considering the late hour? Because it was the most effective way to 
give the punishment meaning in the same way that made the death penalty necessary. Fifth, How would the community benefit from "this revolutionary assumption of arbitrary power?" By establishing safety of life and property.

This exposition by the Alta is striking for its rejection of popular principles. Yet in the same editorial it was "the people" who had enforced "punishment for crime without due process of law," and thus committed treason. It was an act of self-preservation; a "justifiable revolution."48 It was the penultimate act of popular sovereignty: government had been superseded, but not overturned.

The question of whether this revolution was a mass movement, or an action of the few, was left unresolved. The difficulty the Alta had in clarifying the nature of the insurgency reflected the fundamental murkiness of popular action. A significant number, but not a majority, of the city's residents had seen the hanging. But clearly, the bulk of San Francisco's population had not had a hand in the actions of the vigilance committee. How could the "will" of the people be ascertained regarding the hanging? In an absolute sense the people's will could not be ascertained and never can be; the subtlety of each individual's opinion cannot be measured. A society's acceptance of popular sovereignty does allow for some rough measure of the 
people's will to be made. And this was what the Alta was getting at when it wondered whether the committee would be "sustained by the community." 49 Voting might be one way to measure the people's will, but successful action was the definitive measure.

The provocative language of the Alta, approving of insurrection, is especially enlightening when juxtaposed against its editorial comments a few days later. As many of the city's leading merchants were in open rebellion against the constituted authorities, the Alta wrote favorably about the "changed and improved" condition of society. These changes had nothing to do with the vigilance committee, but rather were attributable to social betterment. Families, women, and churches had increased in number while gambling and recklessness had diminished among the general population (i.e. not including the criminal element). The lack of literary and educational opportunities, however, were still glaring deficiencies in San Francisco. Intellectual, social, moral, and religious influences were the keys to building an orderly community. "Intellectual culture is a far better law maker than the politician, and any method which can set men to thinking upon worthy subjects, is far better than the statute which punishes for crimes committed."50 The vigilance committee was a drastic and
49 Ibid., 13 June 1851. 
active method in attempting to achieve social order, but these other, subtler movements were also important.

In the next column the paper reflected on the methods, legal or otherwise, necessary to battle crime. "The times in which we must act do not admit of the consideration of abstract questions of legality."51 The following day the Alta lauded the "astonishing diminution of crime among us in the past week" and attributed it to the danger the vigilance committee posed to criminals. 52

At first glance there might seem to be a contradiction between the Alta's endorsement of both moral instruction and illegal hangings. But both were part of changes that were taking place in san Francisco. The values of a middle class commercial society were colliding with those of the California mining society. San Francisco was suffering from a sort of identity crisis. It was part commercial emporium, eager for the settled ways friendly to business and community growth. But a volatile mass of men interested mainly, if not solely, in sudden riches converged in the city. San Francisco was at once a giant mining camp with a mass of temporary residents and a great metropolis that faced the challenge of maintaining the deportment of a notable and distinguished city.

Merchants found encouragement for a conventional

\footnotetext{
51 Ibid.

52 Ibid., 19 June 1851.
} 
lifestyle with the growing presence of families and churches that supplemented their bourgeois enterprise. Yet the city remained predominately male and transient. Middle class values could hardly seem safe among rootless and rowdy adventurers. Different modes of social domination, some of which appealed to conventional, middle class sensibilities, and some of which were less refined, were evidenced in san Francisco.

The merchants perceived that there was a shameless criminal element (a perception supported by the increase in reported crime) that the authorities were unwilling or unable to effectively punish or control. This criminal element presented an obvious threat to order and appeared to be incorrigible. While the city's temporary residents were not a stable foundation on which to build a middle class city, they could be enlisted to fight its most obvious menace. The men going to and coming from the mines and the merchants shared an affinity for material security. Fortune hunters desired safety for their fortune or potential fortune. Pity for thieves and robbers was non-existent in San Francisco. The lines that separated the merchant class and the mining class were blurry at best. The desire for order (a typically middle class impulse) collided with the mining camp atmosphere created by the impermanence of the city's population. The collision of middle class and mining cultures resulted in systematic and relatively moderate 
vigilante action.

The committee was organized under a constitution. An executive committee made most of the decisions but some were submitted to the general membership for approval. Hubert Howe Bancroft maintained that "all power was lodged" with the executive committee and that it gave "all orders."53 The city was divided into districts and patrolled by a police force of about 100 men directed by a chief of police and five deputy marshals. A separate force, the water police, kept an eye on the activities in the bay and its environs. The headquarters of the committee were manned around the clock, always ready to receive information about suspicious goings-on and, if necessary, summon the committee. At its height the committee counted 707 members. Members also "carefully watched" various trials, an activity that Williams dubbed "supervision." 54

During the approximately three months the committee was active it arrested 91 persons. Of these four were hanged, one whipped, fourteen deported with their passage paid by the committee, fourteen more ordered to leave (threatened with execution if they failed to do so), fifteen turned over to the authorities, and forty-one discharged (two were unaccounted for and Williams suspected they were discharged

53 Hubert Howe Bancroft, The Works of Hubert Howe Bancroft, vol. 36, Popular Tribunals, vol. 1, (San Francisco: The History Company Publishers, 1887), 240. 54 Mullen 170-171; Williams, 222-226, 320, 289. 
as well). The water police examined 495 arrivals. Twentyfive of these were suspected to be ex-convicts, but only seven were sent back to sydney. ${ }^{55}$ The committee's activities hardly resembled the "war of extermination" against criminals that the Alta's correspondent "Justice" had threatened in early June. ${ }^{56}$ Most of those charged with crimes punishable by death under California law were turned over the authorities.

The four hangings were the focal points of the committee's operation. The Jenkins hanging was a spontaneous act: he was caught, tried, sentenced, and executed within hours. In this way it differed from the subsequent hangings, which were premeditated. But like the other hangings the vigilantes and their supporters insisted that it was "the present state of municipal affairs [which] demanded the assumption of power."57 It was the feebleness or corruption of the authorities that made vigilantism necessary.

In the wake of the Jenkins hanging the Alta found reason for optimism. The Recorder's Court lacked the "vast numbers" of burglary and larceny cases which had formerly clogged it. Additionally no prisoners were attempting to escape from jail. These happy developments were traced to

\footnotetext{
55 Williams, 361-362, 236.

56 Alta, 8 June 1851.

57 Ibid., 12 June 1851.
} 
the criminal element's fear of the vigilance committee. ${ }^{58}$

Two days later the Alta cited the opinion of an "old policeman" that the most important factor in the "astonishing diminution of cases" before the Recorder was the enforcement of the midnight closing law on establishments that served alcohol. The closures deprived criminals of "rendezvous from which to sally forth and commit robbery or murder." "There is no doubt," asserted the Alta, "that enforcement of the ordinance in this matter has had a very beneficial effect." The Recorder deserved "great credit" for his part in it. ${ }^{59}$ During July the Alta expressed alarm at the "enormous quantity of small groggeries" which produced their own "Jersey lightnin'. "60 In August the Board of Aldermen passed an ordinance that allowed establishments that posted a $\$ 10,000$ bond to stay open past midnight. The Alta complained that this was a "step backward."61 Enforced moderation in the consumption of alcohol was another imposition of middle class expectations which paralieled, and complemented, the work of the vigilance committee.

Bryan white found that the Recorder heard 22 cases for alcohol violations during the first four months of 1851 , but
58 Ibid., 19 June 1851.
59 Ibid., 21 June 1851.
60 Ibid., 18 June 1851.
61 Ibid., 16 August 1851. 
that the figure jumped to 53 for May, then dropped off slightly to 44 for June, 42 for July, and 39 for August. The number of cases then rose again to 45 in september, 55 in October, and 65 and 61 in November and December. 62 Alcohol enforcement was steady and reflected an emerging attitude which did not countenance drunken carousing. Sobriety was a middle class virtue and the Alta's concerns about alcohol reflected an interest in changing san Francisco into a more civilized community. It saw better restaurants and hotels as one means to this end. Businesses that were "more reconciled to sociable and refined pursuits of pleasure, and the habits of life as they maintain elsewhere, than to the reckless, drifting, temporary nature of our present-day existence" would make San Francisco a better place. It was up to the city's residents to eradicate dissipation: "By our loose -- immoral -alienations from enlightened manners and customs as a community, we encourage vice and create a broad field for the spread of every species of immorality."63 Though this call for cultivation seems far removed from extralegal hangings, it was part of the same impulse to impose social control. Prior to each of the vigilantes' next two hangings, the Alta called for restraint on the part of the committee. Alcohol consumption, dining, and vigilantism all

\footnotetext{
62 White, passim.

63 Alta, 28 July 1851.
} 
required a level of discipline and moderation. Discipline and moderation reflected bourgeois expectations. San Francisco's future as a settled, commercial city depended upon propriety in its public behavior.

JAMES STUART

James stuart had been convicted of the notorious Jansen robbery in February and now was standing trial in Marysville for murder. On July 1, a prisoner suspected of stealing a trunk was brought to the committee rooms. The next morning John Sullivan came to take his turn at guard duty and identified the suspect as James stuart. As it turned out, the man in Marysville who had been convicted of the Jansen robbery was an innocent man, Thomas Berdue, not stuart.

The night of July 8 , stuart began writing a lengthy confession. It detailed a long criminal career and implicated a number of people, including the port warden and some police officers. Meanwhile the city attorney, Frank Pixley, who had defended stuart previously and had insisted in February that the suspect in custody (Thomas Berdue) was not stuart, obtained a writ of habeas corpus ordering the committee to turn over their prisoner (the actual Stuart). .64

The Alta counseled the vigilantes to turn stuart over

64 Williams, 252-253; Mullen, 179-181. 
to the authorities: "An order issued out of the highest Court of the state is entitled to respect, and the disobedience of it would be a dangerous precedent to establish." The paper expressed confidence that stuart would be justly punished by the courts because "the action of the Committee has already incited the Courts to a performance of their duty" in other cases. It was "better to yield in this case an obedience to the law, and then see that the law in the punishment of stuart, if found guilty, be strictly enforced."65 The Alta suggested that there were appropriate limits to vigilantism, even that which was under the direction of the most respectable members of the community.

The vigilantes shuttled stuart between several hiding places (including a city alderman's house) and prevented the sheriff from executing the writ. It was not to be the last time the committee defied such a writ. In five other cases it refused to turn prisoners over to the authorities. ${ }^{66}$

Stuart accused Pixley of having permitted perjured testimony to be presented on his behalf in his trials for larceny in Sacramento. He also charged the attorney with the appropriation of $\$ 500$. Pixley angrily denied the charges. The committee never took action against Pixley, one of their most persistent critics. Their open defiance
65 Alta, 9 July 1851.
66 Williams, 264-267. 
of the authorities did not extend to personal confrontations with the officials themselves. For revolutionaries the vigilantes seemed careful not to disturb the men who ran the machinery of government. ${ }^{67}$

On July 11, stuart was hanged by the committee. The Alta reported it as "The Tragedy of Yesterday." The report's description of the events again did not distinguish between the hanging as an action of the community or the action of a select few: "Once more have the people of San Francisco risen in their awful majesty to visit upon a guilty man the punishment due to his crimes." But it was the vigilance committee which had been "compelled ... to take the law into their own hands, and protect the lives, property, and families of their defenceless fellow citizens." By hanging stuart "the Committee of Vigilance have [sic] discharged this duty to the community."68

The Alta ardently supported the committee's punishment of "known and confessed criminals," but at the same time was anxious that it act with restraint. The committee had been "sustained by the great majority" of the community; it was "deliberate and just," punished "only the guilty," and had studiously avoided a "direct collision with the legally constituted authorities."69 How quickly the Alta forgot
67 Williams, 253, 266.
68 Alta, 12 July 1851.
69 Ibid., 15 July 1851. 
its admonishments regarding the writ of habeas corpus. Still, the Alta "deeply deplored" the hanging, while acknowledging it was necessary, and the committee itself was said to "deeply regret the necessity" of the hanging. ${ }^{70}$ The editor's uncertainty as to how to respond to the actions of the committee is striking.

The Alta seemed intent on convincing itself that the vigilantes subscribed to the civic humanist tradition of disinterested, moderate leaders who acted only in the public interest. The Alta feared a plausible outcome of an unchecked popular movement, that authority would be reduced to physical force. The paper understood the opposition to the committee as "not so much directed against the past acts of the Committee, as against the probable abuses to which such organizations almost invariably lead." If the "present excited state of the public mind," continued, the Alta worried, it would not be long until, "it will be a question of physical strength between the Vigilance Committee" and the authorities. This said, tre Alta bravely claimed it did not fear a "civil war" because San Franciscans could be trusted for their "integrity, industry, and good sense."71 The contention that the vigilantes' virtue would prevent them from abusing their power was something the Alta asserted and doubted simultaneously.

\footnotetext{
70 Ibid., 12 July 1851.

71 Ibid., 17 July 1851 .
} 
Part of the reason the Alta continued to support the committee (despite its obvious discomfort with the potential it carried for social disorder), was the hope that it would impose a new social order. The old rowdy San Francisco might be swept away "by the purification and regeneration of our social system and the complete restoration of our commercial prosperity."72 It was a middle class vision for the future.

The Alta's increasingly equivocal support of the comittee was further illuminated in its response to Governor John McDougal's proclamation asking Californians to support their state and local authorities. The governor admitted that government may have been deficient in the past but promised that improvements had been made that rendered the voluntary associations of vigilantes throughout the state unnecessary. The Alta judged the Governor's proclamation to be "temperate, firm, and probably commendable."73

This willingness to return to conventional means of law enforcement was influenced by the perception that the vigilantes had caused the courts to speed up their work. A new criminal code was also seen as beneficial. The Alta opined that if the public officials would do their duty, the

72 Ibid., 15 July 1851.

73 Ibid., 23 July 1851. Other towns in California had formed vigilance committees modeled on that of San Francisco. See Williams, 249-250, 374-386, 406-407. 
vigilance committee would no longer be needed. ${ }^{74}$ As

August began it summarized the new conditions:

The excitement of the public mind consequent upon the proceedings of the vigilance Committee has nearly passed away; and although that organization is still kept up, it has now more the character of a conservator of public justice than an executor of the law of self-preservation. Our courts are more energetic, circumspect and honest -- our lawyers less technical and unscrupulous -- our police a little more efficient -- and our citizens are more confident, united, hopeful and determined. ${ }^{75}$

White's figures support the conclusion that the authorities had been moved to action. In August the overall rate of cases brought before the Recorder skyrocketed, due to an increase of over 400 per cent, compared to July, in the number of ordinance violations considered. Measured by cases brought before the Recorder, property crime plummeted by over 400 per cent between June and August, while violent crime plunged 360 percent during the same period. ${ }^{76}$

A newfound confidence in the authorities was exhibited by the committee in early August. Four men implicated by Stuart, including the notorious burglars George Adams and

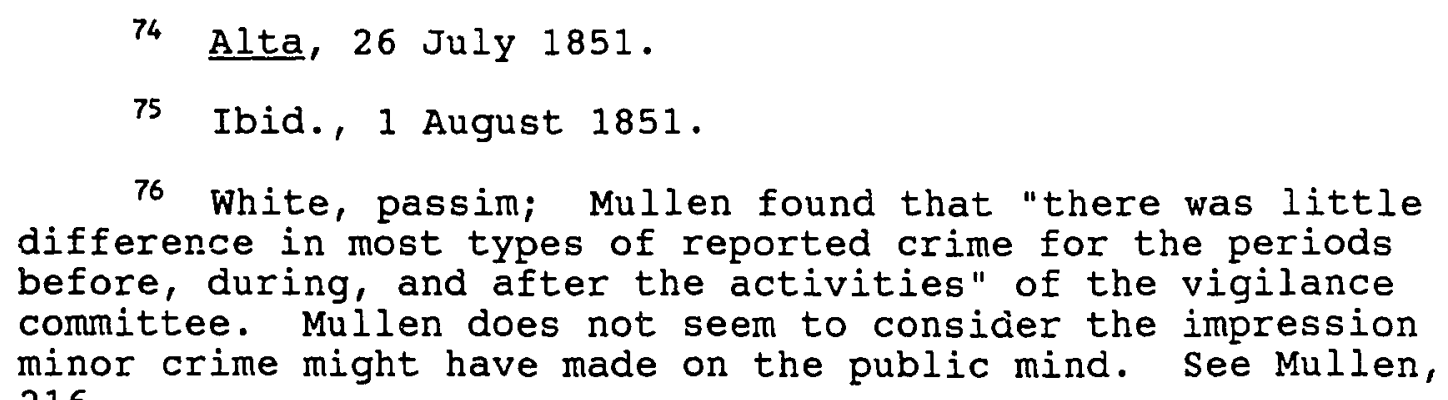
difference in most types of reported crime for the periods before, during, and after the activities" of the vigilance committee. Mullen does not seem to consider the impression minor crime might have made on the public mind. See Mullen, 216. 
James Burns ("Jimmy from Town"), were turned over to the authorities for prosecution. 77 The Alta found in the committee's surrender of Adams "a declaration that our lives and property are secure in the hands of the authorized government." The committee's recent confidence in the authorities was fortunate as there "could not be law and revolution co-existent." Either the "organized and legal government must have full and entire sway, or it must be overturned."is The Alta seemed relieved that the action of the committee had not degenerated into the overthrow of government.

By limiting the duration and nature of their insurrection the vigilantes left government intact. The Alta believed that San Francisco had "passed through a revolution and ended where we began." Because in the American tradition the distinction between popular action and law was ambiguous, neither was invariably viewed as superior. Practical conditions dictated the choice between the two. And the Alta worried whether the time was right for the committee to relinquish control to the authorities (i.e. popular action give way to law). While strongly supporting what it viewed as the committee's acquiescence to the government, the paper wondered if the criminal element

7 Williams, 288-289.

78 Alta, 7 August 1851 . 
would perceive this as "weakness" and a return of crime, "malfeasance and judicial and legal corruption" would result. ${ }^{79}$

\section{A COLLISION WITH THE AUTHORITIES}

August began with the prospect of a rainy winter inculcating a spirit of optimism for the important fall trading season. "Business of every kind is reviving," the Alta happily reported. ${ }^{80}$ But the coming trading season did not end the work of the committee. The public perception of the committee's demise impelled the committee to publicly make clear that it had not dissolved. ${ }^{81}$

The city's tranquility was shattered on August 20, when a posse led by the governor and mayor made its way into the vigilantes' headquarters and spirited away two men who had purportedly been sentenced to death by the committee. ${ }^{82}$ The direct collision between the authorities and the committee that the Alta had fretted about, seemed to have come. The Alta severely condemned the "legal rescue" of the prisoners, but also admitted its propriety:

It is a matter of serious regret that an

79 Ibid.

80 Ibid., 11 August 1851.

81 Ibid., 8 August 1851.

82 Williams, 294-298; Mullen, 206-207. 
occurrence so calculated to lead to acerbity and bitierness of feeling between the authorities and the Vigilance Committee should have been enacted at this late day, when all elements of peace and good order were combining to render our city and state secure against the depredations of the lawless and the abandoned.

Yet, because of the probability that the committee was going to execute the men, "there can be no doubt that the authorities acted properly," and as they were bound to do by their oaths of office. ${ }^{83}$

Much of the blame lay with the vigilantes themselves. "When the Vigilance Committee delivered Adams into the hands of the authorities, they acknowledged by that act that the causes which called the organization into being had ceased to exist." It was now up to the authorities to demonstrate that they were "competent and anxious to promote the public good by enforcing law and punishing crime." Suggestions that the vigilantes retake the prisoners by force were dismissed by the $\underline{\text { Alta }}$ as "intemperate counsels." 84 Though the action of the authorities in seizing the prisoners was rash, it did show their determination to act energetically in dealing with the issue of crime. The Alta was willing to give the courts a chance to prove their revitalization as protectors of life and property.

On the $24 t h$, however, the vigilantes employed a series
83 Alta, 21 August 1851.
84 Ibid. 
of ruses to gain access to the prisoners at the city jail. Samuel Whittaker and Robert Mckenzie, who had confessed to robbery to the committee, were whisked through the city to the committee's rooms, where they were hanged almost immediately. ${ }^{85}$

The Alta was disturbed and troubled by the incident but ultimately sustaired the committee. Two events connected with the affair particulariy offended the paper's sensibilities. A man whose normal occupation was that of a humorist, gave a "severe" speech advocating that whittaker and McKenzie be forcefully taken from the authorities. After applauding these remarks, several in the crowd requested he sing a satirical song ("The old Common Council have Vamoosed the Ranch"). The Alta was scandalized by this frivolity on such a serious occasion. ${ }^{86}$ Then, during the hanging itself, some of the crowd shouted their approval and a few vigilantes stood behind the executed men and recognized friends in the audience. This behavior exhibited, lectured the Alta, "very little reverence for the sacredness and solemnity of death, to say the least." 87 This sort of conduct was not acceptable in popular action that was to be moderate and dignified. It suggested the danger of unchecked popular action.

85 Williams, 299-302; Mullen, 207-208.

86 Alta, 22 August 1851.

87 Ibid., 25 August 1851. 
But the taking and hanging of the prisoners was approved of by the Alta. "Whilst we regret that the Vigilance Committee have by this act, been brought into direct collision with the constituted authorities, we cannot but approve their course in executing the two criminals." The hangings stemmed from the "terrible effects of misrule" and were the "fruits of maladministered laws." Happily the paper perceived a "settled determination on the part of the body politic to have justice done." 88 one result of the summer's vigilantism was a public desire for order.

The stimulation of a sense of public spirit was the legacy of the committee in the A+t's mind. "Their determined and considerate action has restored public confidence." 89 Because of the committee's work "there is an end to the sentiment of insecurity." And should thre be a threat to public peace and order in the future, the example of the vigilance committee had awakened "a power competent and determined to preserve it." 90

Although the Alta returned to the vigilante fold following the hanging of Whittaker and Mckenzie, the incident took its toll on the committee's support. A contemporary reported that the "brutal levity [which] characterized the execution ... so shocked public sentiment
88 Ibid.
89 Ibid., 23 August 1851.
90 Ibid., 1 september 1851. 
that the popular approval of the Committee was greatly weakened, and contributions were withdrawn."91 A religious paper, the Pacific, which had supported the committee previously, condemned the hanging. ${ }^{92}$

\section{POLITICS?}

There was disagreement brewing within the committee as to how it should proceed. Some of the vigilantes wanted to get the committee directly involved in politics. The endorsement (by 14 vigilantes) of an "Independent" ticket moved the Alta to proclaim that the ticket had "been sanctioned by most of the members of the vigilance committee."93 Later, however, the ticket, was officially repudiated by the committee. A resolution was adopted and printed in the papers that expressed the committee's belief that "it is ruinous to the objects of our formation for us to recognize any ticket of a political character." 94

The Alta quickly took up the committee's official position that the Independent candidates were not sanctioned by the committee. But the paper did see the slate of candidates as the culmination of what it hoped for the

\footnotetext{
91 Williams, 301.

92 Ibid., 302.

93 Alta, 27 August 1851.

94 Ibid., 29 August 1851.
} 
committee:

a political step of this kind, characterized by such fairness and consistency -- stamped with the honest intention and patriotic desire of a numerous class of our best citizens -- would, naturally enough, be regarded as a vigilance nomination by all who respect the cause in which men sacrifice selfish and personal considerations for the accomplishment of the generai good. 95

A call for a meeting regarding the Independent (or nonpartisan) ticket was signed by 203 men, of whom something more than a third were vigilantes. The call emphasized the signatories connection with the committee. The "great interests for which many of us have labored the last three months," an obvious reference to the work of the committee, the announcement asserted, could only be culminated by electing a non-partisan ticket to govern San Francisco. 96 At the meeting over 1500 men pledged themselves to the nonpartisan ticket. In the september election the Independents purportedly controlled 1000 to 1300 votes of the approximately 5700 cast. While Independents who also had the endorsement of the Whigs or Democrats won, no candidate running only as an Independent won. ${ }^{97}$

It is clear that individual members of the committee were deeply involved in the election. And the ticket was not without its detractors. Some charged that it was

95 Ibid., 28 August 1851.

96 Ibid., 29 August 1851.

97 Williams, 324-326. 
controlled by the "landed interest" and dubbed it the "Monopolist" ticket. Committee president, Stephen Payran, was accused of attempting to coerce the vigilance committee to support his candidacy for County Recorder, a charge he vigorously denied. ${ }^{98}$

The division that accompanied the committee's foray into politics and the hangings of Whittaker and Mckenzie illustrated the misgivings and doubts of some vigilantes as to the committee's proper role and the bounds, if any, on its conduct. The vitality of the committee seeped away in late August and September as several members resigned. 99 The Executive Committee reported on September 6, that "Our labours are now completed."100

\footnotetext{
98 Alta, 30 August 1851 .

99 Williams, 333-337.

100 Ibid. 335.
} 
CHAPTER VI

CONCLUSION

In the autumn of 1851 the vigilance committee faded but did not disappear. A new executive committee of forty-five was elected and the general committee adjourned. This new executive committee did not have the power to make arrests and its main purpose was to watch over the city and summon the general committee should an emergency arise. There were a few minor incidents over the next several months but, for practical purposes, the active operations of the committee had been suspended. The executive committee continued to meet, but with decreasing frequency. 1

In May 1856, the committee reorganized. As the 1856 committee was much larger than the 1851 committee there were many new members, but there were also holdovers from the earlier committee. The membership certificates of the 1856 committee bore the inscription "Reorganized," and the official medal were imprinted, "Organized 9th June, 1851.

1 Mary Floyd Williams, History of the San Francisco Committee of Vigilance of 1851 (Berkeley, California: University of California Press, 1921; reprint, New York: De Capo Press, 1969), 336-355. 
Reorganized 14th May, 1856."2 The immediate causes of the revival of the vigilance committee were the killings of U.S. Marshal W.H. Richardson and bombastic newspaper editor James King of William. The vigilantes declared that San Francisco's government was fundamentally corrupted. A false-bottomed ballot box, reputed to have been used in the 1854 city elections, served as a symbol of the subversion of the democratic process. ${ }^{3}$ Over the summer the vigilantes hanged four men, ${ }^{4}$ banished dozens, intercepted a shipment of federal arms on its way to the state militia, and even arrested and jailed a justice of the state supreme court. In August, a vigilante contingent 6,000 strong, marched through the city in a symbolic closing of the committee's work. ${ }^{5}$ In reality vigilantism was but the first phase of

2 Ibid., 400-401.

3 Robert M. Senkewicz, Vigilantes in Gold Rush San Francisco (Stanford, California: Stanford University Press, 1985), 118; Hubert Howe Bancroft, The Works of Hubert Howe Bancroft vol. 37, Popular Tribunals vol. 2, (San Francisco: The History Company, 1887), has an illustration of the infamous ballot box, 7 .

4 The death toll of the committee might be placed at five if the suicide of James Sullivan, who killed himself while in vigilante custody, is included. Philip J. Ethington, "The Structures of Urban Political Life: Political Culture in San Francisco, 1850-1880" (Ph.D. diss., Stanford University, 1991), 93; Roger W. Lotchin, San Francisco, 1846-1856: From Hamlet to City (Lincoln, Nebraska and London: University of Nebraska Press, 1974), 194; Josiah Royce, California: From the Conquest in 1846 to the Second Vigilance Committee in San Francisco (Boston: Houghton Mifflin, 1886; reprint, New York: Alfred A. Knopf, 1948), 360 ; Senkewicz states that Sullivan was deported, 113 .

5 Williams, 401-403; Ethington, 92-93. 
the group's labors. The committee converted itself into the People's Party and was the preeminent political power in san Francisco for the next ten years.

Many of the members of the vigilance committee of 1851 had been reluctant to enter the political arena under the vigilante banner. The committee's ambivalence resulted in a dissipation of vigilante energy. In the public mind the vigilantes had not gone too far because they had left government intact. This was important because it allowed the 1851 committee to become a symbol of civic responsibility. Vigilantism became an honored phase of community building in San Francisco and this can be understood in light of the American tradition that glorified revolution and representative government.

The vigilantes (supposedly, at least) succeeded in securing life and property and stimulating more effective law enforcement (i.e. more effective government). ${ }^{6}$ Sympathizers of the committee felt that the vigilantes had not harmed government because their actions had taken place outside of government. Their exercise of authority had been justified by a notion of popular sovereignty that power

6 Lotchin, Senkewicz, and Peter Decker suggest the 1851 committee had the temporary effect of reducing crime. Bancroft agrees with them: "The reformation of 1851 was superficial and temporary; that of $1856 \mathrm{radical}$ and permanent." Bancroft, vol. 37, 531; Lotchin, 194; Senkewicz, 88; Decker, Fortunes and Failures: White collar Mobility in Nineteenth-Century San Francisco (Cambridge, Massachusetts and London: Harvard University Press, 1978), 124 . 
ultimateiy rested in the people. Thus while honoring the revolutionary experience of America, they had also honored its ideal of government. The committee was at once forceful and moderate, dangerous and stabilizing. It was the threat the committee posed to existing government that made it a formidable force for social control. The vigilantes had acted as the sovereign people without destroying the creation of the sovereign people.

For its supporters the vigilance committee was the exemplar of popular action. The vigilantes of 1856 took advantage of the reverence for the 1851 committee and pursued its logical conclusion: political power.

The vigilance committee of 1856 has often been characterized as a revolution. ${ }^{7}$ But this is too strong an appellation. The vigilantes never exercised popular constituent sovereignty to change the form of government. 8 On the contrary, after briefly flouting the law, they joined, and largely constituted, the establishment. The People's Party that the vigilantes organized dominated San Francisco for the next ten years. But the People's Party's candidates stood for election like other aspirants to

7 Royce called the 1856 committee a "Business Man's Revolution," 346; Lotchin discusses the "Revolution of 1856," 261-263; Bancroft called the 1856 movement "one of the grandest moral revolutions the world has ever witnessed," vol. 37, 531, but rejected the characterization of vigilantism in California as politically revolutionary, see vol. $36,28,42$.

8 Bancroft, vol. 36,42 . 
political power. The vigilante power ultimately acquiesced to political institutions.

Vigilantes, as individuals and as a group, exercised power directly. Their authority came from themselves; it was their individual and collective shares of sovereignty that sanctioned their actions. In contrast, political authorities do not utilize their own share of sovereignty but act as agents of the people; their power is vested in them by others. Thus others can take that power away. The only check on vigilante conduct, as the Alta had nervously understood, was their personal virtue. Vigilantes cannot be voted out of power. They must either retire of their own prerogative or be driven out by force. But a political party can be voted out of power. When the vigilantes conformed to orthodox methods of governance by entering the political arena, they voluntarily altered the way in which they exercised authority. They gave up the direct, physical potency of vigilantism for a consignment of power from the electorate to whom they remained accountable.

Power naturally inheres in men according to the theory of popular sovereignty. It exists outside and independent of government. In an unadulterated condition, popular sovereignty closely resembles anarchy. The strong impose their will through force; the force of numbers.

During the early years of the gold rush, California seemed almost to be in a state of nature. Institutions were 
weak and poorly developed. The proliferation of mining camps required that informal mechanisms of government be set up repeatedly. Men in California came to be familiar with the direct exercise of sovereign power. The imposition of social order by the community's most vigorous elements, through force, was an accepted way of life in California. The vigilantes in San Francisco reflected this feature of life in California.

The American tradition has recognized the power of popular sovereignty in its Declaration of Independence. But the nation has been sustained by the integration of this power into government as embodied by the Constitution. A revolutionary impulse lives on, but it has been subordinated to government. In San Francisco, the 1856 vigilance committee closed the circle that had been opened by the gold rush. The powerful vigilantes decided to throw themselves into conventional government. 
Alta California. 1849-1851.

Appleby, Joyce, "Republicanism in Old and New Contexts," William and Mary Quarterly 43 (January 1986): 20-34.

- Capitalism and a New Social Order: The Republican Vision of the 1790s. New York and London: New York University Press, 1984 .

Ashworth, John. 'Agrarians and Aristocrats': Party Ideology in the United States, 1837-1846. Atlantic Highlands, New Jersey: Humanities Press Inc.; London: Royal Historical Society, 1983.

Bailyn, Bernard. The Ideological Origins of the American Revolution. Cambridge, Massachusetts: Harvard University Press, 1967.

Bancroft, Hubert Howe. The Works of Hubert Howe Bancroft. vols. 36 and 37, Popular Tribunals. vols. 1 and 2 . San Francisco: The History Company Publishers, 1887.

Beard, Charles A. An Economic Interpretation of the Constitution of the United States. New York: Free Press, London: Collier Macmillan, 1935.

Becker, Carl. The Declaration of Independence: A Study in the History of Politicai Ideas. New York: Random House, 1922; reprint, 1942 .

Conley, Patrick T. Democracy in Decline: Rhode Island's Constitutional Development, 1776-1841. Providence: Rhode Island Historical Society, 1977.

Decker, Peter R. Fortunes and Failures: White Collar Mobility in Nineteenth-Century San Francisco. Cambridge, Massachusetts and London: Harvard University Press, 1978.

Dennison, George M. The Dorr War: Republicanism on Trial, 1831-1861. Lexington, Kentucky: The University Press of Kentucky, 1976. 
Ethington, Philip J. "The Structures of Urban Political Life: Polj.tical Culture in San Francisco, 1850-1880." Ph. D. diss., Stanford University, 1991.

Gettleman, Marvin E. The Dorr Rebellion: A Study in American Radicalism, 1833-1849. New York: Random House, 1973.

Grimsted, David, "Rioting in Its Jacksonian Setting," American Historical Review 77 (1972): 361-397.

Hartz, Louis. The Liberal Tradition in America. New York: Harcourt, Brace, 1955.

Hofstadter, Richard. The American Political Tradition and the Men Who Made It. New York: Alfred A. Knopf, 1948.

Holliday, J. S. The World Rushed In: The California Gold Eush Experience. New York: Simon and Schuster, 1981.

Howe, Daniel Walker. The Political Culture of the American Whigs. Chicago and London: The University of Chicago Press, 1979.

Johansen, Dorothy, "A Working Hypothesis for the Study of Migrations." Pacific Historical Review 36 , no. 1 (February 1967): 1-12.

Johnson, David A., "Vigilance and the Law: The Moral Authority of Popular Justice in the Far West." American Quarterly 33 (winter 1981): 558-586.

- Founding the Far West: California, Oregon, and Nevada, 1840-1890. Berkeley, Los Angeles, and Oxford: University of California Press, 1992.

Johnson, Paul E. A Shopkeeper's Millennium: Society and Revivals in Rochester, New York, 1815-1837. New York: Hill and Wang, 1978 .

Kramnick, Isaac, "The 'Great National Discussion': The Discourse of Politics in 1787," William and Mary Quarterly 45 (January 1988): 3-32.

- Republicanism and Bourgeois Radicalism: Political Ideology in Late Eighteenth-Century England and America. Ithaca and London: Cornell University Press, 1990 .

Lasch, Christopher. "The Origins of the Asylum." Chap. in The World of Nations. New York: Alfred A. Knopf, 1973. 
Lotchin, Roger w. San Francisco, 1846-1856, From Hamlet to City. Lincoln, Nebraska and London: University of Nebraska Press, 1974.

McWilliams, Carey. California: The Great Exception. New York: Current Books, 1949.

Meyers, Marvin. The Jacksonian Persuasion: Politics and Belief. Stanford, California: Stanford University Press, 1957.

Morgan, Edmund S. Inventing the People: The Rise of Popular Sovereignty in England and America. New York and London: W.W. Norton and Company, 1988.

Mullen, Kevin J. Let Justice Be Done: Crime and Politics in Early San Francisco. Reno and Las Vegas: University of Nevada Press, 1989.

Nash, Gary B. The Urban Crucible: Social Change, Political Consciousness, and the Origins of the American Revolution. Cambridge, Massachusetts and London: Harvard University Press, 1979.

Onuf, Peter S., "Reflections on the Founding: Constitutional Historiography in Bicentennial Perspective," William and Mary Quarterly 46 (April 1989): 341-375.

Pangle, Thomas L. The Spirit of Modern Republicanism: The Moral Vision of the American Founders and the Philosophy of Locke. Chicago and London: The University of Chicago Press, 1988.

Paul, Rodman. California Gold: The Beginning of Mining in the Far West. Iincoln, Nebraska: University of Nebraska Press, 1947 .

Pessen, Edward. Jacksonian America: Society, Personality, and Politics. Homewood, Illinois: The Dorsey Press, 1969 .

- Riches, Class, and Power Before the Civil war. Lexington, Massachusetts and London: D.C. Heath and Company, 1973.

Pocock, J.G.A. The Machiavellian Moment: Florentine Political Thought and the Atlantic Republican Tradition. Princeton, New Jersey: Princeton University Press, 1975. 
Pocock, J.G.A. and Ball, Terence. Conceptual Change and the Constitution. Lawrence, Kansas: University Press of Kansas, 1988 .

Royce, Josiah. California, From the Conquest to the second Vigilance Committee in San Francisco. Reprint, New York: Alfred A. Knopf, 1948.

Ryan, Mary P. Cradle of the Middle Class: The Family in Oneida County, New York, 1790-1865. Cambridge and New York: Cambridge University Press, 1981.

Saxton, Alexander. The Indispensable Enemy. Berkeley, Los Angeles, and London: University of California Press, 1971.

Schlesinger, Arthur M., Jr. The Age of Jackson. Boston: Little, Brown and Company, 1945.

Sellers, Charles. The Market Revolution: Jacksonian America, 1815-1846. New York and Oxford: The Oxford University Press, 1991 .

- Jacksonian Democracy. Washington, D.C.: The American Historical Association, 1958.

Senkewicz, Robert M. Vigilantes in Gold Rush San Francisco. Stanford, California: Stanford University Press, 1985.

Shalhope, Robert E., "Toward a Republican Synthesis: The Emergence of an Understanding of Republicanism in American Historiography," William and Mary Quarterly 29 (January 1972): 49-80.

Shinn, Charles Howard. Mining Camps: A Study in American Frontier Government. 1885, reprint, New York: Alfred A. Knopf, 1948 .

Sinopoli, Richard C., "Liberalism, Republicanism, and the Constitution," Polity 19, no. 3 (1987): 331-352.

Stewart, George Rippey. Committee of Vigilance: Revolution in San Francisco, 1851. Boston: Houghton Mifflin, 1964.

Taylor, Bayard. Eldorado, or, Adventures in the Path of Empire: Comprising a Voyage to California, via Panama; Life in San Francisco and Monterey; Pictures of the Gold Region. New York: G. P. Putnam and Son, 1850, 1862; Reprint, New York: Alfred A. Knopf, 1949.

Taylor, George Rogers. The Transportation Revolution, 1815- 
1860. New York: Reinhart, 1951.

Walters, Ronald G. American Reformers, 1815-1860. New York: Hill and Wang, 1978.

Watson, Harry L. Liberty and Power: The Politics of Jacksonian America. New York: Hill and Wang, 1990.

Watts, Steven. The Republic Reborn: War and the Making of Liberal America, 1790-1820. Baltimore and London: The Johns Hopkins University Press, 1987.

Wilentz, Sean. Chants Democratic: New York City and the Rise of the American Working Class, 1788-1850. Oxford and New York: Oxford University Press, 1984.

Williams, Mary Floyd. History of the San Francisco Committee of Vigilance of 1851. Berkeley, California: University of California Press, 1921; reprint, New York: De Capo Press, 1969.

Wills, Garry. Cincinnatus: George Washington and the Enlightenment. Garden City, New York: Doubleday and Company, 1984.

White, Bryan. "Crime in San Francisco, 1851." Unpublished research paper, Portland State University, n.d.

Wood, Gordon S. Creation of the American Republic, 17761787. New York: W.W. Norton, 1972.

., "Democracy and the Constitution." In How Democratic is the Constitution?, 1-17. ed. Goldwin, Robert and Shambra, William. Washington, D.C.: A.E.P., 1980 .

-, "Interests and Disinterestedness in the Making of the Constitution." In Beyond Confederation: Origins of the Constitution and American National Identity, 69109. ed. Botein, Stephen and Carter, Edward C. Chapel Hill, North Carolina: University of North Carolina Press, 1987. 